\title{
Exploring the observational constraints on the simulation of brown carbon
}

\author{
Xuan Wang ${ }^{1, a}$, Colette L. Heald ${ }^{1,2}$, Jiumeng Liu ${ }^{3}$, Rodney J. Weber ${ }^{4}$, Pedro Campuzano-Jost ${ }^{5,6}$, Jose L. Jimenez ${ }^{5,6}$, \\ Joshua P. Schwarz ${ }^{7}$, and Anne E. Perring ${ }^{6,7}$ \\ ${ }^{1}$ Department of Civil and Environmental Engineering, Massachusetts Institute of Technology, Cambridge, MA, USA \\ ${ }^{2}$ Department of Earth, Atmospheric and Planetary Sciences, Massachusetts Institute of Technology, Cambridge, MA, USA \\ ${ }^{3}$ Atmospheric Sciences and Global Change Division, Pacific Northwest National Laboratory, Richland, WA, USA \\ ${ }^{4}$ School of Earth and Atmospheric Sciences, Georgia Institute of Technology, Atlanta, GA, USA \\ ${ }^{5}$ Department of Chemistry, University of Colorado Boulder, Boulder, CO, USA \\ ${ }^{6}$ Cooperative Institute for Research in Environmental Sciences, University of Colorado Boulder, Boulder, CO, USA \\ ${ }^{7}$ Chemical Sciences Division, Earth System Research Laboratory, National Oceanic and Atmospheric Administration, \\ Boulder, CO, USA \\ ${ }^{a}$ now at: School of Engineering and Applied Sciences, Harvard University, Cambridge, MA, USA
}

Correspondence: Xuan Wang (wangx@seas.harvard.edu)

Received: 12 July 2017 - Discussion started: 19 July 2017

Revised: 19 November 2017 - Accepted: 25 November 2017 - Published: 19 January 2018

\begin{abstract}
Organic aerosols (OA) that strongly absorb solar radiation in the near-UV are referred to as brown carbon $(\mathrm{BrC})$. The sources, evolution, and optical properties of $\mathrm{BrC}$ remain highly uncertain and contribute significantly to uncertainty in the estimate of the global direct radiative effect (DRE) of aerosols. Previous modeling studies of BrC optical properties and DRE have been unable to fully evaluate model performance due to the lack of direct measurements of $\mathrm{BrC}$ absorption. In this study, we develop a global model simulation (GEOS-Chem) of $\mathrm{BrC}$ and test it against $\mathrm{BrC}$ absorption measurements from two aircraft campaigns in the continental US (SEAC ${ }^{4} \mathrm{RS}$ and DC3). To the best of our knowledge, this is the first study to compare simulated $\mathrm{BrC}$ absorption with direct aircraft measurements. We show that $\mathrm{BrC}$ absorption properties estimated based on previous laboratory measurements agree with the aircraft measurements of freshly emitted $\mathrm{BrC}$ absorption but overestimate aged $\mathrm{BrC}$ absorption. In addition, applying a photochemical scheme to simulate bleaching/degradation of $\mathrm{BrC}$ improves model skill. The airborne observations are therefore consistent with a mass absorption coefficient (MAC) of freshly emitted biomass burning OA of $1.33 \mathrm{~m}^{2} \mathrm{~g}^{-1}$ at $365 \mathrm{~nm}$ coupled with a 1-day whitening $e$-folding time. Using the GEOS-Chem chemical transport model integrated with the RRTMG radiative trans-
\end{abstract}

fer model, we estimate that the top-of-the-atmosphere allsky direct radiative effect (DRE) of OA is $-0.344 \mathrm{Wm}^{-2}$, $10 \%$ higher than that without consideration of $\mathrm{BrC}$ absorption. Therefore, our best estimate of the absorption DRE of $\mathrm{BrC}$ is $+0.048 \mathrm{Wm}^{-2}$. We suggest that the DRE of $\mathrm{BrC}$ has been overestimated previously due to the lack of observational constraints from direct measurements and omission of the effects of photochemical whitening.

\section{Introduction}

Carbonaceous aerosols, including both black carbon (BC) and organic aerosols $(\mathrm{OA})$, are among the largest sources of uncertainty in the estimate of the global direct radiative effect (DRE) and forcing (DRF) of aerosols. BC is the principle light-absorbing aerosol in the atmosphere, whereas OA is generally considered as "white carbon" which scatters light without corresponding absorption. However, a fraction of OA is also found to efficiently absorb light, predominately at near-UV wavelengths (Kirchstetter et al., 2004; Hecobian et al., 2010; Arola et al., 2011). This absorbing OA, referred to as brown carbon $(\mathrm{BrC})$, has primarily been associated with biofuel or biomass combustions (Andrea et al., 2006; Ra- 
manathan et al., 2007; Washenfelder et al., 2015). These BrC emissions are typically mixed with co-emitted BC and nonabsorbing OA, challenging the measurement community's ability to evaluate the optical properties of ambient $\mathrm{BrC}$. Additional sources of $\mathrm{BrC}$, including the photo-oxidation of volatile organic compounds (VOCs) and aqueous-phase chemistry in cloud droplets, typically produce less absorbing $\mathrm{BrC}$, with properties that are even more uncertain (Graber and Rudich, 2006; Ervens et al., 2011; Wang et al., 2014; Laskin et al., 2015). A few studies have attempted to simulate $\mathrm{BrC}$ in global models and estimate its DRE (Park et al., 2010; Feng et al., 2013; Lin et al., 2014; Wang et al., 2014; Jo et al., 2016; Saleh et al., 2015). These estimates range from +0.03 to $+0.6 \mathrm{Wm}^{-2}$, corresponding to up to $40 \%$ of the total absorption of carbonaceous aerosol across studies. Due to our poor understanding of the sources, optical properties, chemistry, and mixing state of $\mathrm{BrC}$, the uncertainty surrounding the global absorption from $\mathrm{BrC}$ remains high.

Most modeling studies follow a similar approach to simulating $\mathrm{BrC}$ : some fraction of $\mathrm{OA}$ is assumed to be $\mathrm{BrC}$ and assigned different optical properties from non-absorbing $\mathrm{OA}$. The assumed optical properties of $\mathrm{BrC}$ are based on laboratory measurement of organics extracted in water, acetone, methanol, or other organic solvents. However, these properties are not well constrained by laboratory studies. First, measured absorption properties differ significantly among studies (Wang et al., 2014). Even within a study, different combustion conditions (e.g., burning temperature) can also lead to up to a factor of 2 difference in absorption properties (e.g., the imaginary part of the refractive index, or the mass absorption coefficient) (Chen and Bond, 2010). Previous modeling studies have typically used either the lower or higher bound from laboratory studies to estimate the minimum or maximum absorption properties of $\mathrm{BrC}$ (Feng et al., 2013; Lin et al., 2014). In addition, it is unclear what fraction of the $\mathrm{OA}$ is $\mathrm{BrC}$ and how this differs with source and ambient combustion conditions (Pokhrel et al., 2017). In laboratory studies organics are not always fully soluble; typically, 40$90 \%$ of the total material can be extracted, depending on the solvent (e.g., $\sim 40 \%$ can be extracted in water and more than $90 \%$ can be extracted in methanol; Chen and Bond, 2010). The absorption properties of the insoluble fraction are unknown. Thus previous modeling studies have applied a range of assumptions: Lin et al. (2014) assumed all primary organic aerosols (POA) from biofuel and biomass emissions and all secondary organic aerosols (SOA) from biogenic and anthropogenic emissions to be BrC; Feng et al. (2013) assumed $66 \%$ of biofuel/biomass POA to be BrC; Wang et al. (2014) assumed $25 \%$ of biomass burning and $50 \%$ of biofuel POA as well as aromatic SOA were brown. There is tenuous scientific support for these assumptions. In addition, extrapolating laboratory experiments to real-world combustion sources may also lead to large uncertainties.

Recent studies show that the $\mathrm{BrC}$ absorption from biofuel or biomass sources is likely affected by combustion ef- ficiency (Chen and Bond, 2010; Saleh et al., 2014; Pokhrel et al., 2016, 2017). A number of modeling studies have attempted to connect $\mathrm{BrC}$ absorption to emission properties, by using the modified combustion efficiency (MCE, a function of $\mathrm{CO} / \mathrm{CO}_{2}$ ) (Jo et al., 2016) or the BC / OA ratio (Park et al., 2010; Saleh et al., 2015). These approaches should better represent the temporal and spatial variability of $\mathrm{BrC}$ emissions and properties; however, in practice these parameterizations are difficult to apply in models given the lack of information regarding burn conditions in emissions inventories. The variability of quantities such as BC / OA or MCE in these inventories reflects differences in fuel types (and the associated emission factors), not burn conditions. Therefore, these studies fail to describe the variation in emissions of $\mathrm{BrC}$ within a given fuel type.

Both of these methods focus primarily on the sources of $\mathrm{BrC}$; however, chemical transformation and the mixing state of $\mathrm{BrC}$ also play an important role in controlling $\mathrm{BrC}$ absorption. In laboratory studies, the absorption of $\mathrm{BrC}$ is found to both increase during the formation or chemical aging of certain types of OA and decrease during oxidation or photolysis (Zhong and Jang, 2011; Flores et al., 2014; Lee et al., 2014; Liu et al., 2016). Field studies provide evidence that BrC may be formed in clouds or during convective transport, due to aqueous-phase chemistry or condensation (Gilardoni et al., 2016; Zhang et al., 2017). Observations also indicate that biomass burning $\mathrm{BrC}$ absorption decreases with photochemical aging with a lifetime of $\sim 1$ day (Forrister et al., 2015; $\mathrm{X}$. Wang et al., 2016). It is likely that the absorption and DRE of BrC would change significantly if these chemical processes were included in models. For the mixing state, the key question is whether $\mathrm{BrC}$ is internally or externally mixed with BC. Previous studies typically assume that $\mathrm{BrC}$ is externally mixed with BC (Liu et al., 2013). When considering BC only, the internal mixing is widely idealized as a core-shell morphology (Jacobson, 2001; Bond and Bergstrom, 2006). When coated by other materials, typically inorganic and nonabsorbing OA, the absorption of $\mathrm{BC}$ will be enhanced by the lensing effect (Jacobson, 2001; Bond et al., 2006). However, if $\mathrm{BrC}$ coats $\mathrm{BC}$, Mie calculations show a lower absorption enhancement for BC. At the same time, the absorption of $\mathrm{BrC}$ itself will decrease since there is less externally mixed $\mathrm{BrC}$ left in the atmosphere. As a result, the mixing state of $\mathrm{BrC}$ will affect the absorption of not only the $\mathrm{BrC}$ but also the BC. This influence is sensitive to the absorption properties of $\mathrm{BrC}$, which are highly uncertain, as we have discussed, and also the proportion of externally/internally mixed $\mathrm{BrC}$, which to the best of our knowledge, has not been measured in the atmosphere. Saleh et al. (2015) investigate this influence and conclude that for a single particle with fixed size $(\mathrm{BC}=150 \mathrm{~nm}$ and $\mathrm{BrC}=200 \mathrm{~nm})$ the global mean absorption DRE of $\mathrm{BrC}$ decreases by $45 \%$ when assuming complete internal mixing (compared to complete external mixing). In this case, $\mathrm{BrC}$ is assumed to not absorb light when serving as the coating material on BC cores. This assump- 
tion is challenging to test given current analytical measurement capabilities. If $\mathrm{BrC}$ shells absorb light, there would be a higher absorption enhancement for $\mathrm{BC}$ when $\mathrm{BrC}$ coats $\mathrm{BC}$.

Observational constraints on $\mathrm{BrC}$ are scarce, thus making it a challenge to test and improve models based on observational evidence. Although the absorption of aerosols is widely measured in the form of absorption aerosol optical depth (AAOD) by satellite or ground-based measurement, these observations include the absorption of both $\mathrm{BrC}$ and other aerosols (primarily BC). In our previous work (X. Wang et al., 2016), we presented a method to distinguish the absorption contributions of $\mathrm{BrC}$ and $\mathrm{BC}$. However, the method can only be used for multiple-wavelength absorption observations with two wavelengths longer than $600 \mathrm{~nm}$ and at least one in the near-UV. Such measurements are currently limited and exhibit large uncertainties. In addition, absorption measurement at very low wavelengths where $\mathrm{BrC}$ dominates absorption would also help constrain the abundance and properties of $\mathrm{BrC}$; however, these wavelengths are not available for current remote sensing observations. Recently, during two aircraft campaigns (DC3 and SEAC ${ }^{4} \mathrm{RS}$; see details in Sect. 2), BrC absorption was directly measured. This provides an opportunity to test the model assumptions. However, properties of $\mathrm{BrC}$, including absorption, chemical transformation, and mixing state, are still challenging to evaluate because of the uncertainty surrounding the simulation of OA mass. Models fail to reproduce the observed magnitude and variation of OA mass concentrations (Heald et al., 2011; Spracklen et al., 2011; Tsigaridis et al., 2014). Thus, it can be challenging to untangle whether any discrepancy between modeled and observed $\mathrm{BrC}$ absorption should be attributed to $\mathrm{BrC}$ properties or $\mathrm{OA}$ mass concentrations. Furthermore, uncertainties surrounding the simulation of BC (Koch et al., 2009; Bond et al., 2013; Wang et al., 2014) may also impact a combustion-based approach (MCE or BC / OA) to simulating $\mathrm{BrC}$.

Given the above context, it is highly challenging to develop and test an accurate model simulation of $\mathrm{BrC}$. A reasonable approach is to test the simplest assumptions for $\mathrm{BrC}$ modeling. In this study, we develop a model simulation of $\mathrm{BrC}$, test it against $\mathrm{BrC}$ absorption measurements from two aircraft campaigns in the United States $\left(\mathrm{SEAC}^{4} \mathrm{RS}\right.$ and DC3), and optimize it to match these observational constraints. To the best of our knowledge, this is the first study to compare simulated $\mathrm{BrC}$ absorption and its vertical variation with direct, continuous aircraft measurements. We explore how assumptions for $\mathrm{BrC}$ sources, processing, and properties impact the comparisons with these observational constraints and estimate the resulting global direct radiative effect of $\mathrm{BrC}$ under these conditions.

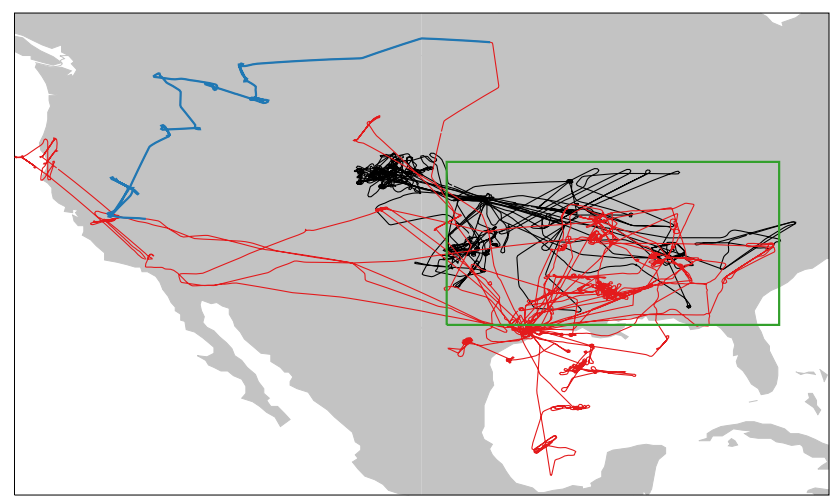

Figure 1. The flight tracks during the DC3 (black) and SEAC ${ }^{4}$ RS (red) campaigns in 2012 and 2013, respectively. The blue tracks indicate the SEAC ${ }^{4} \mathrm{RS}$ data influenced by Rim fires on 26-27 August. The green box indicates the region of focus for our analysis (see Sect. 4 for details).

\section{Aircraft observations}

In this study, we compare our model results to the DC8 airborne measurements from two campaigns: DC3 and SEAC ${ }^{4}$ RS. The DC3 (Deep Convective Clouds and Chemistry) campaign was conducted from May 18 to 22 June in 2012, over the central and southeastern United States (Barth et al., 2015). The SEAC ${ }^{4}$ RS (Studies of Emissions, Atmospheric Composition, Clouds and Climate Coupling by Regional Surveys) campaign occurred in a similar region during 6 August to 23 September in 2013 (Toon et al., 2016). Flight tracks are shown in Fig. 1. BrC absorption and related aerosol measurements of interest were made by the same instruments during these two campaigns.

The OA absorption (hence the $\mathrm{BrC}$ ) was directly measured from liquid extracts of aerosol samples. The samples with aerodynamic diameter smaller than $4.1 \mu \mathrm{m}$ were collected on Teflon $^{\text {TM }}$ filters every $5 \mathrm{~min}$. Water extracts were transferred to an LWCC-TOC system (Liquid Waveguide Capillary Cell coupled to a Total Organic Carbon analyzer). The absorption spectra of the extracts were measured in the 200 to $800 \mathrm{~nm}$ wavelength range; these measurements are referred to as $\mathrm{H}_{2} \mathrm{O} \_$Abs. The detection limit and uncertainty of $\mathrm{H}_{2} \mathrm{O} \_$Abs is $0.031 \mathrm{Mm}^{-1}$ and $20 \%$ respectively, at $365 \mathrm{~nm}$. The insoluble fraction of the samples was sequentially extracted in methanol following the same method as water extracts. This part of the absorption is referred to as $\mathrm{MeOH}_{-} \mathrm{Abs}$ and has a detection limit and uncertainty of $0.11 \mathrm{Mm}^{-1}$ and $37 \%$ at $365 \mathrm{~nm}$. The total absorption of OA is determined by summing $\mathrm{H}_{2} \mathrm{O} \_\mathrm{Abs}$ and $\mathrm{MeOH} \_\mathrm{Abs}$ as reported at $365 \mathrm{~nm}$. A multiplication factor of 2 is applied here to convert the solution absorption to aerosol absorption, reflecting the enhanced absorption by aerosols in the Mie regime versus molecules in the liquid extract (Zhang et al., 2017). This factor corresponds to the measured size distribution at three sites (Liu et al., 2013); this size distribution is similar to that assumed 
in the model (discussed in Sect. 3). An important assumption here is that essentially all of the $\mathrm{BrC}$ can be extracted in water and methanol, which is supported by laboratory experiments (Chen and Bond, 2010). Further details on these measurements can be found in Liu et al. (2015).

In addition to $\mathrm{OA}$ absorption, the mass concentrations of aerosols and gases were measured throughout the two campaigns. Submicron OA (and inorganic aerosols) were measured by a high-resolution time-of-flight Aerodyne Aerosol Mass Spectrometer (AMS, DeCarlo et al., 2006) with an estimated uncertainty of $38 \%$. The transmission of particles through the AMS aerodynamic lens is $\sim 100 \%$ on the range $50-550 \mathrm{~nm}$ and then declines up to above $1 \mu \mathrm{m}$ and is referred to approximately as $\mathrm{PM}_{1}$ (Dunlea et al., 2009). $\mathrm{BC}$ accumulation-mode mass concentrations were measured with a Single Particle Soot Photometer (SP2, Schwarz et al., 2008 ) with an estimated uncertainty of $30 \%$; these measurements were made off a different inlet and sampling line with good transport efficiency only up to $3 \mu \mathrm{m}$ total particle diameter $(50 \%$ transport efficiency at $3 \mu \mathrm{m}$ ). Carbon monoxide (CO) and acetonitrile $\left(\mathrm{CH}_{3} \mathrm{CN}\right)$ were measured with a diode laser spectrometer and proton-transfer reaction mass spectrometry (PTR-MS) with uncertainties of 2 and $20 \%$, respectively. Details on all of these measurements, as well as other aerosol and gas measurements made during the campaigns, can be found in Barth et al. (2015) and Toon et al. (2016).

\section{Model description}

\subsection{The GEOS-Chem model with RRTMG}

We use the global chemical transport model GEOS-Chem (Bey et al., 2001) coupled with the rapid radiative transfer model for GCMs (RRTMG, Iacono et al., 2008) in this study. Our simulations use the GEOS-FP assimilated meteorology from the Goddard Earth Observing System (GEOS) at the NASA Global Modeling and Assimilation office. The global simulations use v10-1 of GEOS-Chem with a horizontal resolution of $2^{\circ} \times 2.5^{\circ}$ and 47 vertical levels. When comparing with aircraft measurements, we perform nested simulations over North America $\left(10-60^{\circ} \mathrm{N}, 130-60^{\circ} \mathrm{W}\right)$ at $0.25^{\circ} \times 0.3125^{\circ}$ horizontal resolution. RRTMG is a radiative transfer model which calculates both longwave and shortwave atmospheric radiative fluxes. This calculation is coupled to GEOS-Chem and conducted every $3 \mathrm{~h}$. Details of the implementation of RRTMG in GEOS-Chem are available in Heald et al. (2014).

The simulation of POA and BC mass is based on the standard GEOS-Chem simulation with modifications described in Wang et al. (2014). The model assumes $50 \%$ of anthropogenic and $30 \%$ of emitted biomass burning organic carbon (OC) is hydrophobic and the remaining is hydrophilic. Hydrophobic OC converts to hydrophilic OC with an $e$-folding time of 1.15 days, equal to an aging rate of $\sim 10^{-5} \mathrm{~s}^{-1}$. The
POA is inferred from simulated primary OC by applying an OA / OC mass ratio of 2.1 (Turpin and Lim, 2001; Aiken et al., 2008; Canagaratna et al., 2015). This represents average atmospheric OA / OC composition. Freshly emitted POA is less oxidized (with an OA / OC range of 1.34-1.65; Canagaratna et al., 2015); however, aging occurs quickly in the atmosphere, in particular for biomass burning OA (Cubison et al., 2011; Forrister et al., 2015). The simulation of BC includes a source-specific treatment. For the fossil fuel BC, we assume $80 \%$ are emitted as hydrophobic and convert to hydrophilic with an aging rate related to $\mathrm{SO}_{2}$ and $\mathrm{OH}$ levels in the atmosphere:

$k=\propto\left[\mathrm{SO}_{2}\right][\mathrm{OH}]+b$,

where $\alpha=2 \times 10^{-22} \mathrm{~cm}^{6}$ molec $^{-2} \mathrm{~s}^{-1}$ and $b=5.8 \times 10^{-7}$ $\mathrm{s}^{-1}$ (Liu et al., 2011; Wang et al., 2014). The biofuel and biomass burning BC is assumed to be emitted as $70 \%$ hydrophilic and $30 \%$ hydrophobic with an aging $e$-folding time from hydrophobic to hydrophilic of $4 \mathrm{~h}$ (note that throughout our analysis "biomass burning" refers to open burning and does not include biofuel). The details of the $\mathrm{BC}$ scheme and evaluation against $\mathrm{BC}$ mass concentrations can be found in Wang et al. (2014). Our simulation of SOA is from the standard GEOS-Chem simulation, which is based on reversible partitioning of semivolatile products of aromatic and biogenic VOC oxidation (Pye and Seinfield, 2010; Pye et al., 2010).

The global anthropogenic emissions of $\mathrm{BC}$ and POA follow the Bond et al. (2007) emission inventory $\left(8.7 \mathrm{TgC}^{-1}\right.$ for POA and $4.4 \mathrm{TgC}^{-1}$ for BC, globally). For the North America region, The EPA National Emission Inventory for 2011 (EPA/NEI11) is used. We also implement the annual scaling factors from the EPA's air pollutant emissions trends data (https://www.epa.gov/air-emissions-inventories/ air-pollutant-emissions-trends-data) and a $17 \%$ decrease for $\mathrm{SO}_{2}$ and a $30 \%$ decrease for $\mathrm{BC}$, suggested by Kim et al. (2015), who conducted an analysis of the aerosols during SEAC ${ }^{4} \mathrm{RS}$. The resulting anthropogenic POA and BC emissions from the contiguous United States total 0.58 and $0.26 \mathrm{TgC} \mathrm{yr}^{-1}$ for 2013. Since the EPA/NEI11 inventory does not separate fossil and biofuel emissions, we apply the fossil/biofuel emission ratios from the Bond et al. (2007) emission inventory and the seasonal cycle of residential emission from Park et al. (2003) to separate these two emission types. This produces an annually averaged fossil / biofuel emission ratio of 8 for BC and 1.2 for OC in the United States. The biomass burning emissions of BC and POA follow the year-specific daily mean GFED4s (Global Fire Emissions Database with small fires) inventory (van der Werf et al., 2010; Giglio et al., 2013), contributing $0.1 \mathrm{TgC} \mathrm{yr}^{-1}$ of BC and $1.42 \mathrm{TgC} \mathrm{yr}^{-1}$ of POA in the United States in 2012 and $0.15 \mathrm{TgC} \mathrm{yr}^{-1}$ of BC and $2.24 \mathrm{TgC} \mathrm{yr}^{-1}$ of POA in the United States in 2013. The biogenic VOC emissions are simulated online based on the MEGAN2.1 (Model of Emissions of Gases and Aerosols from Nature) 
scheme (Guenther et al., 2012). The anthropogenic VOC emissions are based on the combination of REanalysis of the TROpospheric chemical composition (RETRO) global emission inventory (Pulles et al., 2007) and EPA/NEI11 inventory for the United States.

\subsection{Treatment of $\mathrm{BrC}$ optical properties}

Most previous $\mathrm{BrC}$ modeling studies assume some fraction of $\mathrm{OA}$ to be $\mathrm{BrC}$ and assign it different optical properties from non-absorbing OA. Unlike this approach, we assign absorption properties for all OA, thus convolving two unknowns into a single assumption. This simplifies our analysis, given that the total absorption from OA equals the absorption from $\mathrm{BrC}$ :

$$
\begin{aligned}
\mathrm{Abs}_{\mathrm{BrC}} & =\mathrm{Abs}_{\mathrm{OA}}=\mathrm{MAC}_{\mathrm{OA}} \cdot \text { Mass }_{\mathrm{OA}} \\
& =\mathrm{MAC}_{\mathrm{BrC}} \cdot \operatorname{Mass}_{\mathrm{BrC}}=\operatorname{MAC}_{\mathrm{BrC}} \cdot f \cdot \text { Mass }_{\mathrm{OA}} .
\end{aligned}
$$

MAC is the mass absorption coefficient. $f$ is the fraction of $\mathrm{OA}$ mass that is $\mathrm{BrC}$. $\mathrm{MAC}_{\mathrm{OA}}$ is the optical property typically measured in laboratory studies, which includes information on both $\mathrm{MAC}_{\mathrm{BrC}}$ and the contribution of $\mathrm{BrC}$ to $\mathrm{OA}$ $(f)$. Here, to determine $\mathrm{MAC}_{\mathrm{OA}}$, we take the OA properties from the Global Aerosol Data Set (GADS) database (Kopke et al., 1997) with updates from Drury et al. (2010), except for the imaginary part of the refractive index $(k)$.

Little evidence to the contrary, we assume that fossil fuel POA is not absorbing. To date, there are no field observations that indicate POA associated with fossil fuels is lightabsorbing (Laskin et al., 2015) except measurements in Beijing (Yan et al., 2017). For biofuel and biomass burning POA, we use the experimental results from Saleh et al. (2014) to parameterize the imaginary part of the refractive index. In that study, $k$ is related to the $\mathrm{BC} / \mathrm{OA}$ mass ratio from biofuel and biomass emissions:

$w=\frac{0.21}{\frac{\mathrm{BC}}{\mathrm{OA}}+0.07}$

$k_{550}=0.016 \lg \left(\frac{\mathrm{BC}}{\mathrm{OA}}\right)+0.04$,

where $w$ refers to the wavelength dependence of $k$, and $k_{550}$ is the imaginary part of the refractive index at wavelength of $550 \mathrm{~nm}$. For other wavelengths $(\lambda), i$ can be calculated as

$k=k_{550}(550 / \lambda)^{w}$.

The BC / OA emission ratio is associated with both combustion fuel type and burning conditions. In the GFED4s emission inventory, the $\mathrm{BC} / \mathrm{OA}$ emission ratio ranges from $\sim 0$ to 0.23 for biofuel (however the majority of points range between 0.06 and 0.16 , the 10th and 90th percentiles) and 0.03 to 0.06 for biomass burning. These ranges are not large because the variability in burn conditions, which is likely to dominate the variability in $\mathrm{BC} / \mathrm{OA}$ emission ratio, is not represented. We use global average $\mathrm{BC} / \mathrm{OA}$ emission ratios in the model for each source: 0.12 for biofuel and 0.05 for biomass burning. This simple assumption reflects the average burning conditions globally but not for specific fires. The assumed $\mathrm{BC} / \mathrm{OA}$ ratio is further used to derive the wavelength-dependent $k$. The size distribution of OA is assumed to be log-normal, with a geometric median diameter (GMD) of $180 \mathrm{~nm}$ and standard deviation $(\delta)$ of 1.6. The density of OA is assumed to be $1.3 \mathrm{~g} \mathrm{~cm}^{-3}$. Based on these values, the MAC of $\mathrm{OA}$ at $365 \mathrm{~nm}$ is calculated to be $1.19 \mathrm{~m}^{2} \mathrm{~g}^{-1}$ for biofuel OA and $1.28 \mathrm{~m}^{2} \mathrm{~g}^{-1}$ for biomass burning OA. The OA AAE (absorption Ångström exponent) of the 300 and $600 \mathrm{~nm}$ wavelengths pair is 2.6 for biofuel $\mathrm{OA}$ and 3.1 for biomass burning OA. These assumptions will be evaluated in the following comparisons with observations. We choose this approach for our model simulation of $\mathrm{BrC}$ because relationships between the absorption of $\mathrm{OA}$ and the $\mathrm{BC} / \mathrm{OA}$ ratio have been confirmed by field measurements (X. Wang et al., 2016; Gilardoni et al., 2016).

For SOA, we assume that only aromatic SOA absorbs light since experiments show most light-absorbing SOA is related to aromatic carbonyls (Jaoui et al., 2008; Desyaterik et al., 2013) and since absorption from biogenic SOA in the field (in the same region and years studied here) has been found to be negligible compared to even mild biomass burning influence (Washenfelder et al., 2015). We specify the absorption properties of aromatic SOA based on our earlier study (Wang et al., 2014); these are among the highest values from laboratory experiments $\left(\mathrm{MAC}=1.46 \mathrm{~m}^{2} \mathrm{~g}^{-1}\right.$ at $365 \mathrm{~nm}$; Zhang et al., 2013). We note that the model does not include biomass burning SOA.

All of the above assumptions, for both POA and SOA, are the initial properties for our model simulations. The goal of this study is to investigate whether these assumptions are consistent with the absorption properties in the real atmosphere. To distinguish with other simulations described below, we call this the "Base" simulation.

\subsection{Chemical aging of biomass burning $\mathrm{BrC}$}

In the Base simulation, we assume that the absorption properties of organic aerosol are fixed. To investigate the influence of chemical aging, we perform additional simulations with assumptions derived from our previous study (X. Wang et al., 2016). In that study, we found that the $\mathrm{BrC}$ absorption of biomass burning plumes observed at T3 site of the Green Ocean Amazon campaign (GoAmazon2014/5) exhibited a $\sim$ 1-day photochemical lifetime (in sunlight). This photochemical lifetime is qualitatively consistent with the study of Forrister et al. (2015), who investigate the Rim fires during SEAC ${ }^{4} R S$. To the best of our knowledge, these two field studies are the only ones to investigate the change in $\mathrm{BrC}$ absorption during chemical aging. To include this aging effect in the model, we assume that the absorption of OA decreases 
at a rate related to $\mathrm{OH}$ :

$\operatorname{Abs}_{\mathrm{BrC}, t+\Delta t}=\operatorname{Abs}_{\mathrm{BrC}, t} \cdot \exp \left(-\frac{[\mathrm{OH}] \cdot \Delta t}{5 \times 10^{5}}\right)$,

where $\mathrm{Abs}_{\mathrm{BrC}, t}$ and $\mathrm{Abs}_{\mathrm{BrC}, t+\Delta t}$ are the absorption of $\mathrm{BrC}$ at time $t$ and $t+\Delta t$ (in days), and $[\mathrm{OH}]$ is the concentration of $\mathrm{OH}$ in molec $\mathrm{cm}^{-3}$. As both of these studies found that the absorption did not decrease beyond some minimum threshold, we do not allow absorption to drop below a specified minimum (1/4 of the starting point). We add this scheme to the Base simulation described above to conduct a model simulation with aging (Base_Age).

\subsection{Mixing of $\mathrm{BC}$ and $\mathrm{OA}$}

As discussed in Sect. 1, BC and OA are likely to be internally mixed in a form reasonably well modeled with core-shell morphology (China et al., 2015). This morphology enhances the absorption of $\mathrm{BC}$ through lensing, and this enhancement depends upon the absorption properties of the shell material (including $\mathrm{BrC}$ ). However, this is challenging to represent accurately, given uncertainties in the coating thickness and composition. Furthermore, considering the low BC / OA emission ratio from biomass burning and biofuel, together with the typical coating thickness (Moffet and Prather, 2009; Schwarz et al., 2008; Perring et al., 2017), the majority of OA from these sources is generally externally mixed with BC. Indeed multiple field studies have reported that BC is only present in a few percent of the biomass burning particles and that the large majority of the emitted particles do not contain BC (Kondo et al., 2011; Perring et al., 2017). Therefore, we treat $\mathrm{BC}$ and $\mathrm{OA}$ as externally mixed in our simulation. We apply a constant absorption enhancement for BC (1.1 for fossil BC, 1.5 for biofuel/biomass burning BC), as described in Wang et al. (2014), based on a series of laboratory and field observations, regardless of whether the coating shell absorbs light or not. As a result, this value likely represents some average state which includes the influence of BC-OA internal mixing. Our assumption of externally mixed $\mathrm{OA}$ with an associated absorption enhancement for BC may overestimate $\mathrm{OA}$ absorption since the $\mathrm{OA}$ which coats $\mathrm{BC}$ is double-counted; however, given that the majority of the OA is likely externally mixed, this overestimate in absorption is modest and likely negligible for air masses influenced predominantly by biofuel and biomass burning sources.

\section{Comparing simulated BrC to aircraft observations}

In this section, we evaluate our assumptions for $\mathrm{BrC}$ by comparing the GEOS-Chem nested model simulations with aircraft observations from the DC3 and SEAC ${ }^{4} \mathrm{RS}$ campaigns. The region included in the analysis is the central and southeastern United States, which is shown in Fig. 1. We focus on this subset of the measurements because (1) aircraft measurements from both DC3 and SEAC ${ }^{4} \mathrm{RS}$ cover this region; and
(2) the emissions inventories for this region have been evaluated by a series of SEAC ${ }^{4} \mathrm{RS}$ studies (resulting modifications described in Sect. 3.1). Dry aerosol absorption is used when comparing the model with observations since hygroscopic growth is not considered in the measurements. Before evaluating the simulation of OA absorption, we first need to explore the fidelity of the simulation of OA mass.

\subsection{DC3 campaign}

We first compare the Base simulation to observations. Figure 2 compares the median vertical profile of modeled sulfate, $\mathrm{BC}$, and $\mathrm{OA}$ mass concentrations with the DC- 8 aircraft measurements during the DC3 campaign. Our simulation reproduces the median vertical distribution of observed sulfate and $\mathrm{BC}$ but underestimates $\mathrm{OA}$ by about a factor of 2 at low altitudes $(<3 \mathrm{~km})$. To investigate the source of this bias, we show all the observed $1 \mathrm{~min}$ averaged data points together with model results as a "points-to-points" plot in Fig. 3. The model reproduces the BC observations (normalized mean bias (NMB) of $-5 \%$ ) except for some occasional peaks, which are challenging to capture given the limitations of model temporal and spatial resolution. We note here that the model skill in capturing this variability improves in the nested grid $(R=0.54)$ compared to the global $2^{\circ} \times 2.5^{\circ}$ grid ( $R=0.48$ ), with little change in NMB. In comparison, the bias in the simulation of OA is much larger, with an overall NMB of $-45 \%$. The unbiased simulation of sulfate and BC suggests that the model generally captures the transport, deposition, and primary emissions (fossil, biofuel, and biomass burning) of aerosols. Therefore, the underestimate of OA is more likely associated with biased emission factors for POA and/or an underestimate of SOA. A key question is whether this bias is associated with absorbing or nonabsorbing sources of OA.

According to the emission inventories used here, biofuel contributes very little $\mathrm{OA}$ in this region $(<3 \%$ of the total POA source during the campaign). This is consistent with a negligible demand for heating during spring and summer in the southeastern United States. We therefore conclude that it is highly unlikely that the substantial OA underestimation identified in Figs. $2 \mathrm{c}$ and $3 \mathrm{~b}$ is associated with biofuel sources. To investigate whether an underestimate in fire emissions contributes to the bias, we also show the measured acetonitrile $\left(\mathrm{CH}_{3} \mathrm{CN}\right)$ concentrations in Fig. 3c. Acetonitrile is a tracer for biomass burning and biofuel emissions (Andreae and Merlet, 2001). We calculate the hourly correlations between $\mathrm{CH}_{3} \mathrm{CN}$ and $\mathrm{OA}$, and $\mathrm{BC}$ and $\mathrm{OA}$ to help to identify whether the $\mathrm{OA}$ during plumes are associated with fires. When $\mathrm{CH}_{3} \mathrm{CN}$ peaks, $\mathrm{OA}$ peaks, $\mathrm{BC}$ peaks, and high $\mathrm{CH}_{3} \mathrm{CN}-\mathrm{OA}$ correlation are observed, we can be confident that biomass burning dominates the sources of OA. We observe two such periods (BP1 and BP2), which are shown with green shading in Fig. 3. BP1 is a period with a series of $\mathrm{CH}_{3} \mathrm{CN}$ peaks measured in the central United States. The 

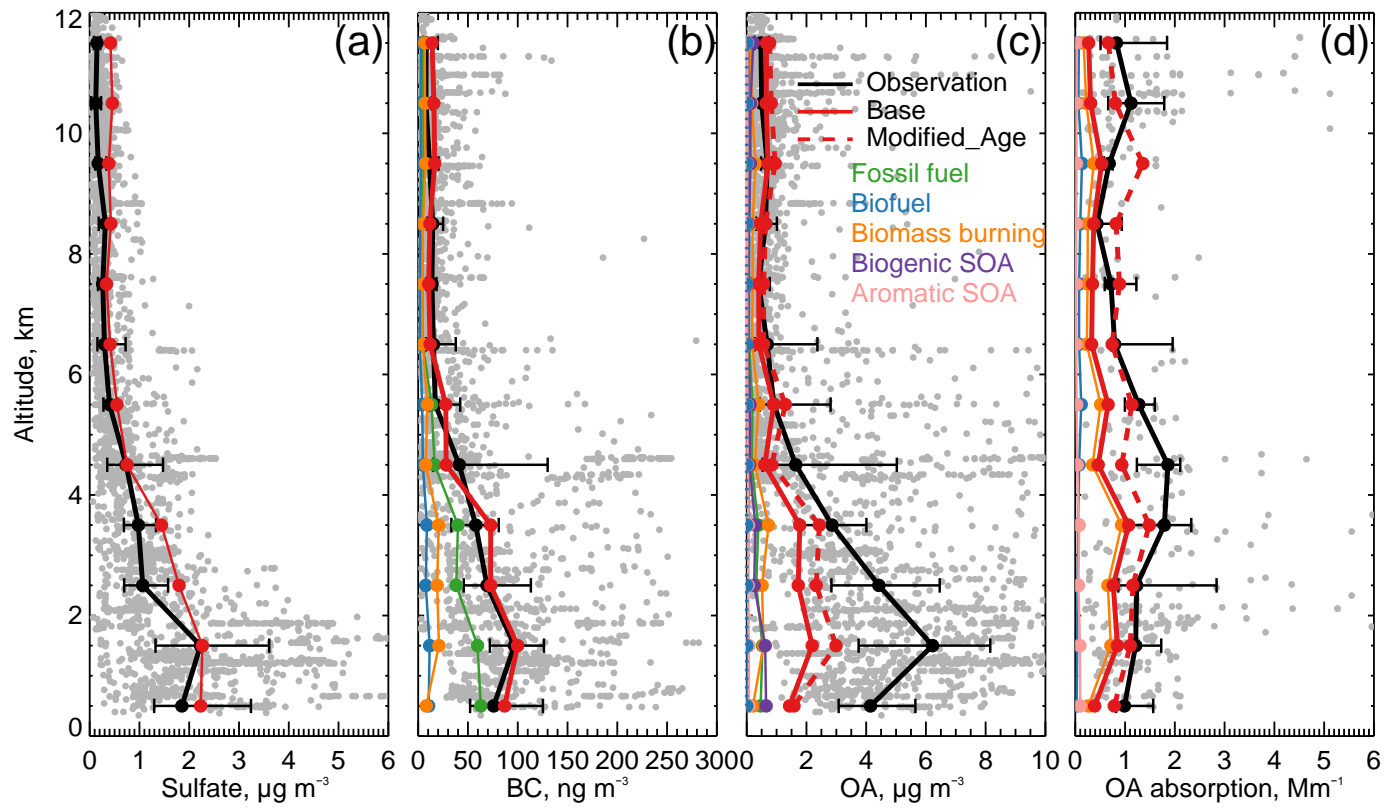

Figure 2. The median vertical profile of (a) sulfate, (b) BC, (c) OA mass concentration, and (d) OA absorption, shown in $1 \mathrm{~km}$ bins, from the DC-8 aircraft measurement during the DC3 campaign in the region shown in Fig. 1. Observations (black) are compared to the Base simulation (red) and source-specific contributions to that simulation, as well as to the optimized Modified_Age simulation (red dashed). Error bars show the 25th and 75th percentiles of measurements in each vertical bin. Gray points show the original measurements (1 min averaged values for $\mathbf{a}, \mathbf{b}$, and $\mathbf{c}, 5 \mathrm{~min}$ averaged values for $\mathbf{d}$ ). The ranges of $x$-axes are set to emphasize the vertical profile, so several data points higher than the maximum values of $x$-axes are not shown. Details regarding the model simulations of Base and Modified_Age can be found in Sects. 3.2 and 4.1 .

correlations between $\mathrm{CH}_{3} \mathrm{CN}$ and $\mathrm{OA}$ are continuously high $\left(R^{2}=0.5-0.9\right)$ throughout the period. Both modeled BC and $\mathrm{OA}$ are dominated by biomass burning and enhanced during BP1 but underestimate the measurements. This suggests that the model does not capture the strength of these plumes. The simulated mass of BC from fires needs to increase by $130 \%$ to match observations. This bias could be associated with transport (including excessive dilution) as well as inaccuracies in the amount or intensity of burning in the emissions inventory or in the emission factor for fire sources of BC. In contrast, the mass of biomass burning OA needs to increase by $210 \%$ to match the observations; this is $\sim 80 \%$ more than for $\mathrm{BC}$. BP2 is a $1 \mathrm{~h}$ period dominated by a biomass burning plume observed in the southeastern United States, with very high $\mathrm{CH}_{3} \mathrm{CN}-\mathrm{OA}$ correlation $\left(R^{2}=0.84\right)$. The model is able to represent the $\mathrm{BC}$ concentrations during this period quite well $(<10 \%$ underestimate); though if we attribute this entire bias to the biomass burning source, it implies a $36 \%$ increase in that source. Similarly, the mass of biomass burning OA needs to increase by $145 \%$, which is also $\sim 80 \%$ more than for BC (similar to BP1). Since the influence from transport and errors in fuel burned should be very similar for $\mathrm{BC}$ and $\mathrm{OA}$, the higher bias in simulated $\mathrm{OA}$ suggests that either the biomass burning $\mathrm{BC} / \mathrm{OA}$ emission ratio is overestimated or that biomass burning constitutes a large source of SOA which has been neglected in the model. If all of the
$80 \%$ difference is due to the overestimate of the $\mathrm{BC} / \mathrm{OA}$ emission ratio, the $\mathrm{BC} / \mathrm{OA}$ emission ratio would need to be reduced to 0.027 to meet the observations; this value is lower than the emission ratio for any fire type in the GFED4s emission inventory. It is therefore unlikely that this difference can be attributed entirely to an overestimate of the BC / OA emission ratio. A number of studies have explored the formation of SOA in biomass burning plumes. Yee et al. (2013) conduct photo-oxidation experiments in their chamber, and find that the formation of SOA from oxidation of phenol, guaiacol, and syringe can be larger than $25 \%$ of the co-emitted biomass burning POA. Ortega et al. (2013) investigate the biomass burning smoke from fuels combusted during the FLAME-3 study and find that the net increase in mass due to biomass burning SOA is $42 \pm 36 \%$ of the biomass burning POA. However, compared to the laboratory studies, aircraft field measurement show much less SOA formation. $\mathrm{Cu}-$ bison et al. (2011), Jolleys et al. (2012), and Shrivastava et al. (2017) have reviewed all aircraft field studies of SOA formation in BB plumes and have found that the increase in total OA from SOA production is most often undetectable, with a smaller fraction of the cases showing increases or decreases with aging, which are a small fraction of the initial POA. Some studies have included simple biomass burning SOA schemes in their models. Hodzic and Jimenez (2011) assume a simplified biomass burning SOA scheme in the 

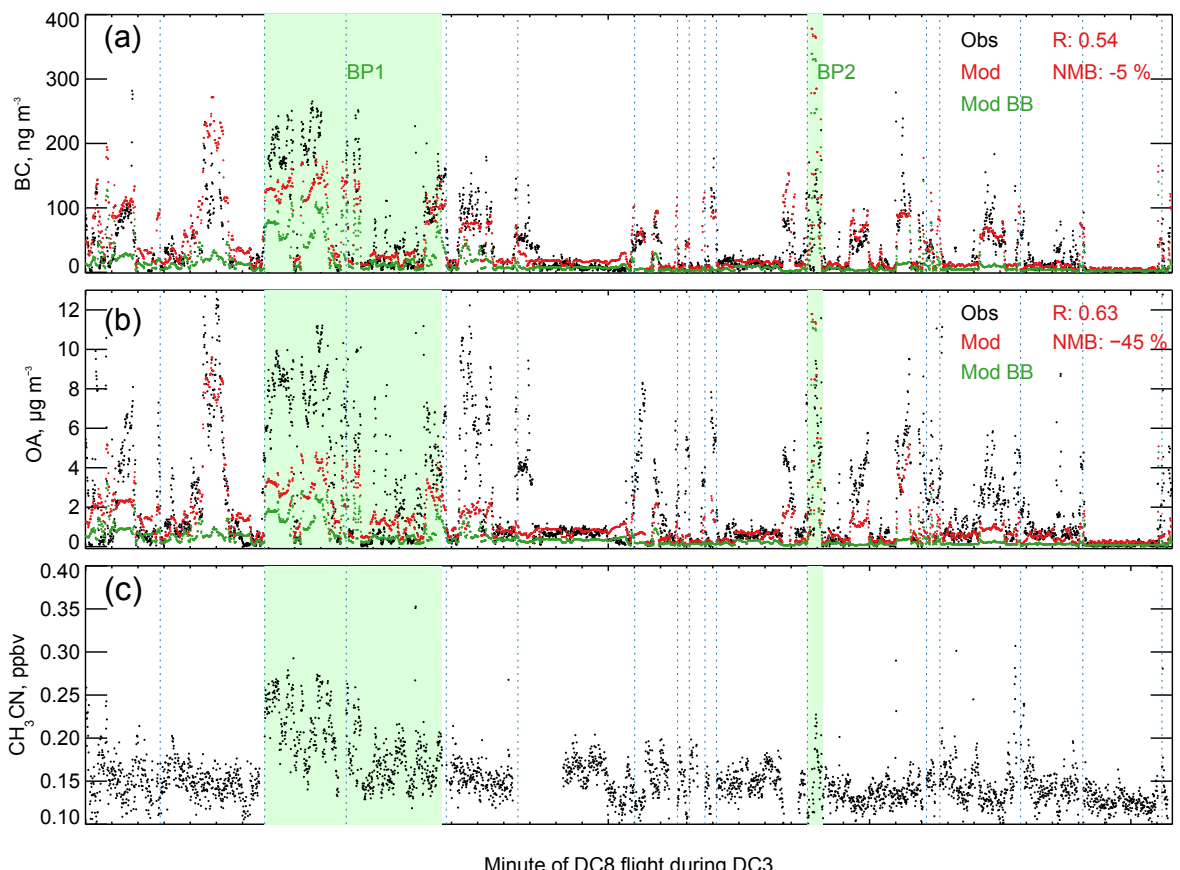

Figure 3. Points-to-points comparison between 1 min averaged observed (black) and simulated (red) (a) BC and (b) OA made aboard the DC-8 aircraft during the DC3 campaign in the region shown in Fig. 1. The simulated total mass concentrations (red) as well as mass concentrations associated with biomass burning only (green) are from the Base simulation. The observed concentrations of acetonitrile are also shown (c). The blue dashed lines separate different flights. The green shading indicates two biomass burning dominated periods (BP1 and BP2, discussed in Sect. 4.1).

CHIMERE model (VOC is oxidized by $\mathrm{OH}$ with a constant rate); their simulation estimates that biomass burning SOA contributes $11 \%$ of the total SOA in Mexico City. Kim et al. (2015) used the same scheme for the SEAC ${ }^{4} \mathrm{RS}$ period and concluded that biomass burning SOA contributed $1 \%$ of the $\mathrm{OA}$ in this region, comparable to $10 \%$ of the biomass burning POA. Therefore it is unlikely that the majority of the $80 \%$ bias can be attributed to SOA formation from fires. The small bias in the simulation of BC during BP2 suggests that the emission factor for $\mathrm{BC}$ from biomass burning is not substantially biased. Rather, it is likely that the bias in BC (particularly in BP1) results from an underrepresentation of total emissions from these fires. In both BP1 and BP2, after adjusting both $\mathrm{BC}$ and $\mathrm{OA}$ mass concentrations upwards to eliminate this bias, we still need to increase OA by an additional $80 \%$ to account for the underestimate of either the POA emission factor or biomass burning SOA. This $80 \%$ represents the upper limit on missing OA associated with biomass burning, given that other sources likely contribute to background concentrations.

Based on the above analysis, we first increase the biomass burning OA mass by 210 and $145 \%$ during BP1 and BP2, respectively, to fix the model bias associated with these specific fire plumes. We then increase the biomass burning OA mass by $80 \%$ for all the remaining data (including background biomass burning $\mathrm{OA}$ ), likely to account for the bias from the
POA emission factor and any missing biomass burning SOA. This modified simulation of OA mass (referred to as FixBB) reflects the highest possible biomass burning contribution. In Fig. 2c, this modified model (same as Modified_Age, described at the end of this section) still underestimates the vertical profile of OA mass. This underestimate can be observed as underestimated OA peaks in Fig. $3 b$ but not in the corresponding $\mathrm{BC}$ concentrations in Fig. $3 \mathrm{a}$, and it is therefore unlikely to be related to combustion sources (fossil fuel, biofuel, or biomass burning). This suggests that the remaining underestimate of $\mathrm{OA}$ is related to anthropogenic and/or biogenic secondary sources, which are not a source of BC. This is consistent with previous work which suggests a general underestimate of SOA in the GEOS-Chem simulation (Heald et al., 2011). Furthermore, OA absorption is not enhanced during these peaks, suggesting that this SOA is not strongly absorbing and these biases are not relevant to our analysis of absorption which follows.

Figure $2 \mathrm{~d}$ compares the simulated median vertical profile of OA absorption with measurements from the DC3 campaign. Note that this vertical profile may not be entirely representative since there are very few data points $(<10)$ available at some altitudes. It is also important to note that the OA particle size may differ between model and observations. The size distribution assumed in the model is for fine-mode particles and would not include the absorption from coarse- 
mode OA ( $>1 \mu \mathrm{m}$ diameter). The biomass burning source contributes $\sim 90 \%$ of the total absorption from OA in our simulation. The model underestimates the OA absorption at both high and low altitudes. At altitudes above $10 \mathrm{~km}$, some of the observations show abnormally high OA absorption considering the correspondingly low submicron OA mass. The model fails to capture these high values even by applying the highest absorption properties from laboratory studies for OA. Zhang et al. (2017) analyzed the inflow and outflow of OA absorption during DC3 and conclude that the high absorption aloft may relate to coarse-mode OA or OA formation during convective transport. A number of studies also suggest that aqueous-phase chemistry in cloud droplets at high altitudes can produce absorbing OA (Ervens et al., 2011; Desyaterik et al., 2013). These sources of OA are not included in our simulation, and given the limited observational constraints provided by this dataset, we do not consider these data further in our study, but we agree with Zhang et al. (2017) that further investigation of high-altitude $\mathrm{BrC}$ is needed. The absorption enhancement in both observations and the model around $4.5 \mathrm{~km}$ is related to biomass burning; this is confirmed by elevated observed acetonitrile concentrations at this altitude. The high concentrations at this altitude are influenced by the fire plumes during BP1.

To investigate the absorption properties of biomass burning OA, we select the data during BP1 as we are confident that nearly all of the $\mathrm{OA}$ absorption is related to biomass burning in this period. Figure 4 compares OA absorption from simulated biomass burning OA with measurements during BP1. The Base modeled biomass burning OA absorption is moderately correlated $(R=0.56)$ with the observations but overestimates them by $\sim 10 \%$. This overestimation increases to more than a factor of 2 after the underrepresentation of fire OA is corrected (FixBB). This suggests that the model assumption for $\mathrm{MAC}_{\mathrm{OA}}$ is too high if no whitening process is included. Given this overestimate, we perform an additional simulation which includes photochemical "whitening" of BrC (described in Sect. 3.3, FixBB_Age); the results are shown as green points in Fig. 4. By applying the aging scheme, the correlation between modeled and observed absorption increases $(R=0.60)$, and the model is brought into much better agreement with observations $(\mathrm{NMB}=-4 \%)$. We note that if the $80 \%$ increase in biomass burning sourced $\mathrm{OA}$ included in FixBB is attributed solely to an overestimate of the BC / OA ratio (which we previously note seems unrealistic), this would imply an $8 \%$ decrease in the MAC following the Saleh et al. (2014) parameterization used here. This suggests that our initial assumption of $\mathrm{MAC}_{\mathrm{OA}}$ is not significantly biased by the potential overestimate of the global $\mathrm{BC} / \mathrm{OA}$ ratio used in our simulation. We further note that the decrease in $\mathrm{MAC}_{\mathrm{OA}}$ required to match observations exceeds the contribution of SOA from biomass burning, and therefore the model cannot be brought into agreement with observations by assuming non-absorbing biomass burning SOA.

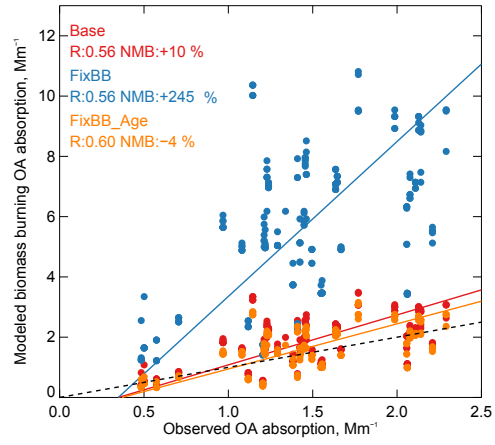

Figure 4. Correlation between observed and modeled OA absorption during the BP1 interval (see Fig. 3) of the DC3 campaign. The 1-to-1 line is shown as a dotted black line; the best-fit lines are shown as solid lines. NMB: normalized mean bias between the simulation and observations. Details of the model simulations can be found in Sect. 4.1.

Figure 4 suggests that our initial assumption of $\mathrm{MAC}_{\mathrm{OA}}$ for biomass burning only needs to increase by $4 \%$ when including the whitening process (decrease by $71 \%$ if not considering aging) to match the observations in BP1. At $365 \mathrm{~nm}$, the best $\mathrm{MAC}_{\mathrm{OA}}$ to represent the measurements is $1.33 \mathrm{~m}^{2} \mathrm{~g}^{-1}$ with aging (this is the MAC for freshly emitted $\mathrm{OA}$ ) and $0.37 \mathrm{~m}^{2} \mathrm{~g}^{-1}$ without aging. The $0.37 \mathrm{~m}^{2} \mathrm{~g}^{-1}$ value is around the lower end of previous experimental studies, whereas $1.33 \mathrm{~m}^{2} \mathrm{~g}^{-1}$ falls close to the median of previous experimental studies (Kirchstetter et al., 2004; Chen and Bond, 2010; Liu et al., 2013; Zhong and Jang, 2011; Zhang et al., 2013). This supports the idea that OA from fresh BB emissions exhibits similar absorption properties as observed in laboratory studies but that including an aging process is important for simulating OA absorption in the ambient atmosphere. Given that there are only three OA absorption measurements available during BP2, we cannot repeat this analysis for BP2. For the other periods not dominated by biomass burning, the correlation between modeled and observed OA absorption is very low $(R<0.1)$. OA absorption is typically lower during these periods and represents a mix of biomass burning and biofuel influences, the combination of which reproduces the magnitude of observed OA absorption.

After applying a series of new model assumptions, which include increasing fire OA mass, decreasing the biomass burning $\mathrm{MAC}_{\mathrm{OA}}$, and adding an aging scheme, we conduct a new simulation (Modified_Age). The simulated vertical profile of OA absorption in this simulation is now able to capture the measurements. Since the observational constraints on $\mathrm{MAC}_{\mathrm{OA}}$ and the aging scheme only affect absorption but not aerosol mass, the simulated OA concentrations in FixBB, FixBB_Age, and Modified_Age are the same. 

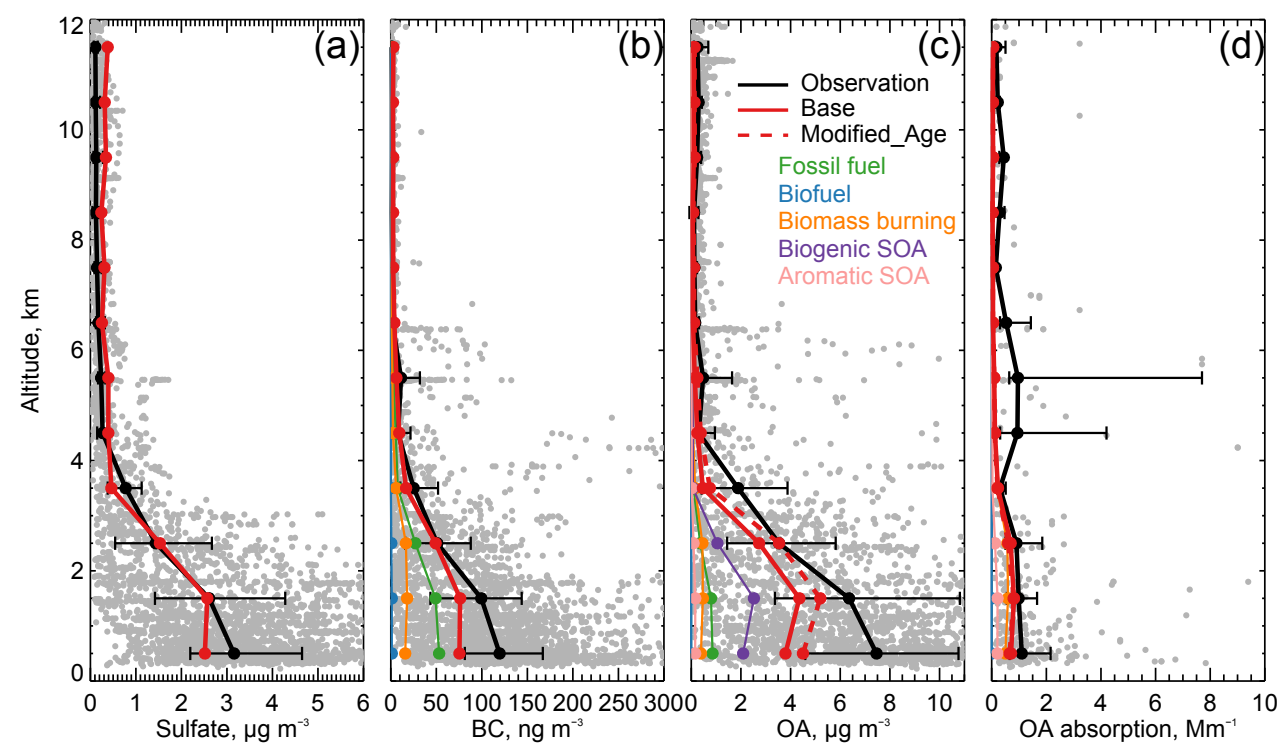

Figure 5. The median vertical profile of (a) sulfate, (b) BC, (c) OA mass concentration, and OA absorption (d), shown in $1 \mathrm{~km}$ bins, from the DC-8 aircraft measurement during the SEAC ${ }^{4}$ RS campaign in the region shown in Fig. 1. Observations (black) are compared to the Base simulation (red) and source-specific contributions to that simulation, as well as to the optimized Modified_Age simulation (red dashed). Error bars show the 25 th and 75 th percentiles of measurements in each vertical bin. Gray points show the original measurement data points (1 min averaged values for $\mathbf{a}, \mathbf{b}$, and $\mathbf{c}, 5 \mathrm{~min}$ averaged values for $\mathbf{d}$ ). The ranges of $x$-axes are set to emphasize the vertical profile, so several data points higher than the maximum values of $x$-axes are not shown. Details of model simulations of Base and Modified_Age can be found in Sects. 3.2 and 4.1 .

\subsection{SEAC $^{4} \mathrm{RS}$ campaign}

The SEAC ${ }^{4} \mathrm{RS}$ campaign offers us the opportunity to test our updated simulation developed based on DC3 measurements with a new dataset. Figures 5 and 6 show the vertical profiles and points-to-points plot for DC-8 aircraft measurements during SEAC ${ }^{4}$ RS. Similar to DC3, our model generally captures the median vertical profile of sulfate (Fig. 5a) and BC (Fig. 5b). During SEAC ${ }^{4}$ RS, biogenic SOA constitutes a much larger source of $\mathrm{OA}$ in the model (compared to DC3). Consistent with DC3, the Base simulated OA absorption captures the observations at low altitudes but is too low at high altitudes. The observed absorption at high altitudes is much lower than observed in DC3. Zhang et al. (2017) suggest that this is because measurements during SEAC ${ }^{4} \mathrm{RS}$ are less influenced by convection than DC3; thus there may be less secondary formation of $\mathrm{BrC}$ during convective transport. Note that there are very few data points available at altitudes above $4 \mathrm{~km}$. The Base model underestimates the OA mass observations, but with a much lower bias $(\sim 50 \%)$ than seen during DC3. Similarly, the model bias for BC is modest (NMB of $-30 \%$ ). There is therefore weaker evidence for missing or underestimated fire activity in the GFED4s inventory during SEAC ${ }^{4}$ RS. Furthermore, Fig. 6c shows that there are no coincident peaks, with both elevated $\mathrm{CH}_{3} \mathrm{CN}$ and $\mathrm{CO}$ correlated to each other. In our selected region, during SEAC ${ }^{4} \mathrm{RS}$, there is no clear period which is dominated by biomass burning. The Rim fires occurred on 26-27 Au- gust 2013. During this period, CO is underestimated by more than $400 \%$ in the model, which indicates that the model fails to reproduce the fire plumes from the Rim fires. However, as shown in Fig. 1, these measurements are located around the northwestern United States and are not included in our analysis.

When applying the same modified model assumptions constrained from DC3 (Modified_Age simulation), the model simulation of observed OA concentrations (Fig. 5c) improves. When only considering altitudes below $4 \mathrm{~km}$ (where there are sufficient measurement data points), OA absorption is very similar between Base and Modified_Age simulations, which are both able to capture the observed values. However, the mean bias in OA mass concentrations between the model and observations decreases from -42 to $-28 \%$ when moving from the Base to the Modified_Age simulation. This confirms that the modifications applied based on the DC3 campaign in 2012 are generally appropriate for this region.

Washenfelder et al. (2015) analyzed measurements of OA absorption at a surface site within the study region (central Alabama) and during a similar time period (June 2013) of SEAC ${ }^{4} \mathrm{RS}$. They found that most of the OA absorption was associated with biomass burning with little contribution from biogenic SOA, consistent with our analysis of the aircraft data. They suggest a biomass burning $\mathrm{MAC}_{\mathrm{OA}}$ of $1.35 \mathrm{~m}^{2} \mathrm{~g}^{-1}$, which is very close to ours. However, as their site was rarely affected by biomass burning $(\sim 6 \%$ of all 

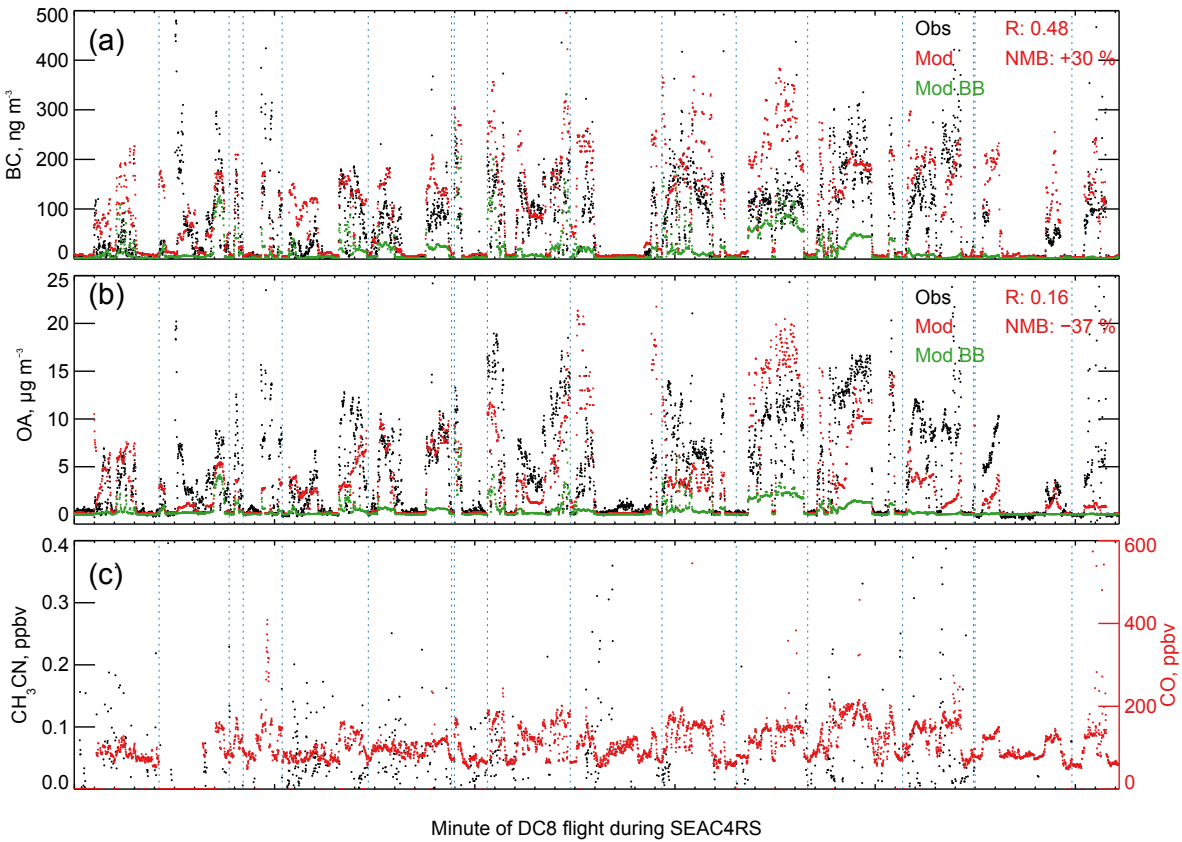

Figure 6. Points-to-points comparison between observed and modeled (a) BC and (b) OA made aboard the DC-8 aircraft during the SEAC ${ }^{4} \mathrm{RS}$ campaign in the region shown in Fig. 1. The modeled total mass concentrations (red) as well as mass concentrations associated with biomass burning only (green) are from the Base simulation. The observed concentrations of acetonitrile and CO are also shown (c). The blue dashed lines separate different flights.

$\mathrm{OA})$, the identification of biomass burning OA absorption properties from this site is challenging and may not be regionally representative.

\subsection{Recommendations for $\mathrm{OA}$ absorption properties}

Although the assumption of a relationship between $\mathrm{BrC}$ absorption and the $\mathrm{BC} / \mathrm{OA}$ ratio, which is applied in our simulations, has been observed in several studies, including both laboratory (Saleh et al., 2014; Pokhrel et al., 2017) and field measurements (X. Wang et al., 2016; Gilardoni et al., 2016), the specific relationship (e.g., slope) differs among these studies. Based on the above analysis, our assumed MAC for fresh biomass burning OA at $365 \mathrm{~nm}$ (based on Saleh et al., 2014) needs to be increased by $4 \%$ to reproduce the observations from DC3 and SEAC ${ }^{4} \mathrm{RS}$ (when including an aging scheme). As discussed in Sect. 4.1, this suggests that the absorption properties of freshly emitted OA are very similar to those from laboratory experiments. As a result, we retain the absorption wavelength dependence based on Saleh et al. (2014) but increase the $\mathrm{MAC}_{\mathrm{OA}}$ by $4 \%$ in the model. Our recommended $\mathrm{MAC}_{\mathrm{OA}}$ for biomass burning is therefore $1.33 \mathrm{~m}^{2} \mathrm{~g}^{-1}$ at $365 \mathrm{~nm}, 0.77 \mathrm{~m}^{2} \mathrm{~g}^{-1}$ at $440 \mathrm{~nm}$, and $0.35 \mathrm{~m}^{2} \mathrm{~g}^{-1}$ at $550 \mathrm{~nm}$, with the suggested aging scheme described in Sect. 3.3. We assume that biomass burning SOA is equally absorbing as primary OA from biomass burning. All of these numbers can be translated to the form of $\mathrm{MAC}_{\mathrm{BrC}}$ if the contribution of $\mathrm{BrC}$ to $\mathrm{OA}$ is known or specified. For example, the MAC $\mathrm{OA}_{\mathrm{OA}}$ of $1.33 \mathrm{~m}^{2} \mathrm{~g}^{-1}$ is equivalent to a $\mathrm{MAC}_{\mathrm{BrC}}$ of $2.66 \mathrm{~m}^{2} \mathrm{~g}^{-1}$ with $\mathrm{BrC}$ contribution of $50 \%$ to total OA. The years 2012 and 2013 were not exceptionally low or high fire years in the United States. During DC3 and SEAC ${ }^{4}$ RS, fires in the United States (e.g., 12586 fires in June 2012, data from www.globalfiredata.org) were somewhat more frequent than the last 10-year average (e.g., average 9831 fires in June). The difference between 2012 and 2013 and 10-year average emissions in our research region during the measurement period is not large (22 and 34\% higher in 2012 and 2013 respectively, compared to the 10-year average). This suggests that our conclusions based on the constraints from these two campaigns can be generalized to other biomass burning seasons in the United States. Given that the measurements only constrain absorption at one wavelength, we cannot evaluate the modelassumed AAE. Previous field and laboratory studies show a large range of $\mathrm{BrC} \mathrm{AAE}$ of 2 to 9 (Laskin et al., 2015). Our model assumption (3.1 for biomass burning OA at 300 and $600 \mathrm{~nm}$ wavelength pair) is around the lower end of this range.

The spring and summer in the southeastern United States are not substantially impacted by biofuel emissions; therefore, the measurements during the DC3 and SEAC ${ }^{4} \mathrm{RS}$ campaigns are not suitable for evaluating the absorption from biofuel OA. Given that we see no model bias when biofuel influence exceeds the biomass burning influence (typically during low absorption background OA periods), we retain 
our assumptions in Sect. 3.2 for biofuel OA. Therefore, our recommended value for biofuel $\mathrm{MAC}_{\mathrm{OA}}$ is $1.19 \mathrm{~m}^{2} \mathrm{~g}^{-1}$ at $365 \mathrm{~nm}, 0.76 \mathrm{~m}^{2} \mathrm{~g}^{-1}$ at $440 \mathrm{~nm}$, and $0.39 \mathrm{~m}^{2} \mathrm{~g}^{-1}$ at $550 \mathrm{~nm}$. We assume that there is no whitening of biofuel OA with aging given that, to date, there is no field evidence to support this. These assumptions require further testing against measurements with significant biofuel influence.

During both DC 3 and SEAC ${ }^{4} \mathrm{RS}$, anthropogenic SOA contributes very little absorption in the model $(\sim 4 \%$ in DC3 and $<1 \%$ in SEAC ${ }^{4} \mathrm{RS}$ ) despite the fact that we apply upper-limit assumptions regarding the absorption properties of SOA. In our analysis of DC3, there remain several underestimated OA mass peaks even after increasing biomass burning OA mass. These peaks are likely due to secondary biogenic or anthropogenic sources. During SEAC ${ }^{4} \mathrm{RS}$, there are also some peaks with substantial simulated biogenic SOA; observed absorption is not elevated during these peaks. Therefore, we conclude that the absorption from biogenic and anthropogenic SOA is negligible in the southeastern United States, consistent with SOAS results (Washenfelder et al., 2015). This may not be true in other regions.

Using the above model configuration (Modified_Age simulation), the model is able to reproduce the vertical profile of OA absorption during DC3 and $\mathrm{SEAC}^{4} \mathrm{RS}$ at altitudes below $10 \mathrm{~km}$ that include more than 340 data points. Our optimized $\mathrm{MAC}_{\mathrm{OA}}$ is comparable with previous $\mathrm{BrC}$ model studies. Feng et al. (2013) assume that $66 \%$ of the OA from biofuel and biomass burning is $\mathrm{BrC}$. They applied two different sets of assumptions for the absorption properties of $\mathrm{BrC}$ : a moderately absorbing $\mathrm{BrC}$ with $\mathrm{MAC}=0.63 \mathrm{~m}^{2} \mathrm{~g}^{-1}$ at $450 \mathrm{~nm}$, and a strongly absorbing $\mathrm{BrC}$ with $\mathrm{MAC}=1.6 \mathrm{~m}^{2} \mathrm{~g}^{-1}$ at $450 \mathrm{~nm}$. These numbers are 0.41 and $1.06 \mathrm{~m}^{2} \mathrm{~g}^{-1}$ when transferring $\mathrm{MAC}_{\mathrm{BrC}}$ to $\mathrm{MAC}_{\mathrm{OA}}$, the median of which $\left(0.74 \mathrm{~m}^{2} \mathrm{~g}^{-1}\right)$ is similar to our assumptions at $450 \mathrm{~nm}$. Jo et al. (2016) assume different $\mathrm{BrC}$ to $\mathrm{OA}$ contributions for different biomass burning and biofuel fuels, resulting in a range of $\mathrm{MAC}_{\mathrm{OA}}$ of $0.65-5.01 \mathrm{~m}^{2} \mathrm{~g}^{-1}$ at $365 \mathrm{~nm}$. The assumptions of Saleh et al. (2015) and Q. Wang et al. (2016) are also based on the laboratory results from Saleh et al. (2014) but use the modeled BC / OA mass concentration ratio instead of emitted $\mathrm{BC} / \mathrm{OA}$ ratio. The modeled $\mathrm{BC} / \mathrm{OA}$ mass concentration ratio reflects the mixed contribution of various sources and the effect of differential removal during transport; it is not equivalent to the initial emission properties of carbonaceous aerosol. They assume that all $\mathrm{OA}$ from biofuel and biomass burning is $\mathrm{BrC}$ and apply a $\mathrm{MAC}=2.5 \mathrm{~m}^{2} \mathrm{~g}^{-1}$ for biofuel $\mathrm{OA}$ and $3.1 \mathrm{~m}^{2} \mathrm{~g}^{-1}$ for biomass burning OA at $550 \mathrm{~nm}$. These values are much higher than ours and higher than any of the previous experimental studies. Although some of these modeling studies compare their simulated total AAOD with observations, none evaluates their assumptions with direct $\mathrm{BrC}$ absorption measurements.

Simulating the whitening process of $\mathrm{BrC}$ as we do in our Modified_Age simulation comes at a computational cost of adding extra species or tracking absorption in a model, something which may not be practical for all 3-D models. If we neglect the whitening of $\mathrm{BrC}$ with aging in our simulation, we must further reduce the $\mathrm{MAC}_{\mathrm{OA}}$ for biomass burning to match the observational constraints. In this case, we estimate an average $\mathrm{MAC}_{\mathrm{OA}}$ for biomass burning of $0.37 \mathrm{~m}^{2} \mathrm{~g}^{-1}$ at $365 \mathrm{~nm}, 0.23 \mathrm{~m}^{2} \mathrm{~g}^{-1}$ at $440 \mathrm{~nm}$, and $0.10 \mathrm{~m}^{2} \mathrm{~g}^{-1}$ at $550 \mathrm{~nm}$; we call this the Modified_Simple simulation. Another approach to simplify the whitening process for models may be to apply constant whitening factors with altitude to the simulated absorption; the consistency of these factors may require additional observational support.

\section{Global implications}

The model assumptions applied in Modified_Age and Modified_Simple are constrained and tested against conditions influenced by US fires observed during DC3 and SEAC ${ }^{4}$ RS. We assume that such constraints are generalizable though the combustion conditions may differ in other regions. We test this assumption in Sect. 5.1 by comparing our global simulation with AAOD observations outside of the United States. In this analysis, we conduct Modified_Age and Modified_Simple simulations with a horizontal resolution of $2^{\circ} \times 2.5^{\circ}$, using 2014 meteorology and 10-year averaged biomass burning emissions (2005-2014).

\subsection{Surface absorption and AAOD of $\mathrm{BrC}$}

We use the results from Modified_Age to conduct the analysis in this section. Both of the Modified_Age and Modified_Simple simulations are optimized to meet the observational constraints and therefore exhibit very similar average surface absorption. We note that the Modified_Age scheme creates a somewhat sharper contrast in absorption from land to ocean (as aging during transport whitens the $\mathrm{BrC}$ ) than the Modified_Simple scheme; however, the suite of observations currently available (and discussed here) would not capture this gradient and therefore cannot be used to discriminate between these two schemes.

Figure 7 shows the global distribution of surface OA dry absorption contributions (i.e., BrC absorption contribution) to total absorption from aerosols at $370 \mathrm{~nm}$. The modeled contribution ranges from 5 to $72 \%$ globally, with an average value of $32 \%$. The circles in Fig. 7 show the BrC absorption contributions from observations at eight surface sites. These data are derived from multiple years' multiple-wavelength absorption measurements from Aethalometers (AE, Magee Scientific, http://www.mageesci.com), using a BC-BrC absorption separation method. Details of this methodology and the specific datasets can be found in X. Wang et al. (2016). Although the model assumptions were optimized based on measurements in the United States, the model is able to represent the $\mathrm{BrC}$ absorption contribution at sites in Europe. 


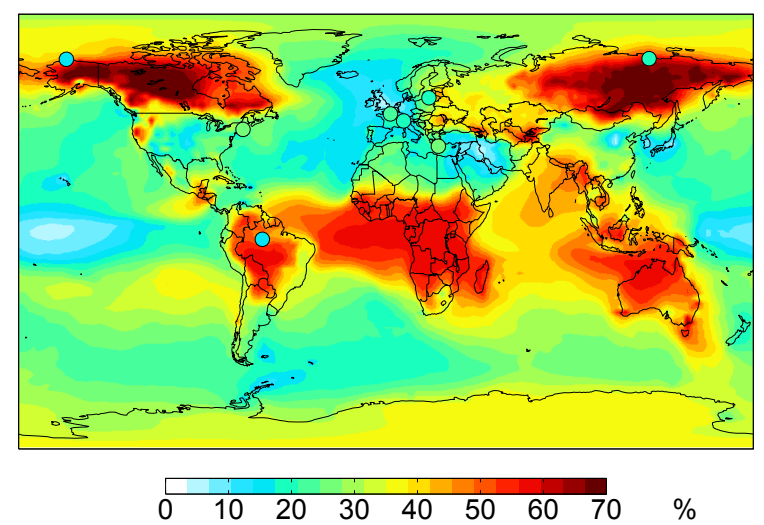

Figure 7. Global distribution of simulated BrC dry absorption contribution to total dry aerosol absorption at $370 \mathrm{~nm}$ at the surface for 2014. Results are from the Modified_Age simulation. The circles show the retrieved results from multiple-wavelength absorption measurements at 8 surface sites (see Sect. 5.1 for details).

However, the model shows much higher $\mathrm{BrC}$ absorption contributions than observations in other fire-rich regions (e.g., Amazon and Siberia). The simulated contributions reflect 10year averaged values over all seasons, but the measurements over these eight sites are not continuous and usually cover several months in a year. Therefore, this is not an exact comparison between the model and these measurements.

Figure 8 shows the global distribution of simulated column BrC AAOD and the contribution of BrC AAOD to total AAOD at $440 \mathrm{~nm}$. The BrC AAOD at $440 \mathrm{~nm}$ ranges from $\sim 10^{-5}$ to 0.05 , with a global mean of 0.002 . BC still dominates the total AAOD in most regions. The contribution of $\mathrm{BrC}$ AAOD to total AAOD at $440 \mathrm{~nm}$ ranges from 15 to $70 \%$, with a global mean of $46 \%$. The Aerosol Robotic Network (AERONET) provides a worldwide measurement network of AAOD at four wavelengths (440, 675, 870 , and $1020 \mathrm{~nm}$ ). However, several shortcomings limit its use for constraining modeled $\mathrm{BrC} \mathrm{AOOD}$, which include the uncertainties in AERONET retrievals, possible inconsistencies between assumptions in the retrieval scheme and our model, poor data availability, no data at low wavelengths where $\mathrm{BrC}$ dominates absorption, and the influence from dust. Details of the processing and the uncertainty issues surrounding AERONET AAOD are discussed in X. Wang et al. (2016). When assuming only BC absorbs light, the modeled AAOD has a moderate correlation with AERONET AAOD at $440 \mathrm{~nm}(R=0.54)$. This correlation is smaller than that at $675 \mathrm{~nm}(R=0.59)$, where OA contributes nearly no absorption. After including the absorption from $\mathrm{BrC}$, the correlation of AAOD at $440 \mathrm{~nm}$ increases to $R=0.60$; this increase in model skill qualitatively supports our description of BrC absorption.

These comparisons suggest that our simulation, optimized based on observations in the United States, is not substantially biased in other regions of the world. However, we em- phasize that we have developed a simple approach to modeling $\mathrm{BrC}$, and more observations are needed to refine this simulation for other regions where sources and optical properties may differ.

\subsection{Estimating the direct radiative effect (DRE) of $\mathrm{BrC}$}

Figure 9a and $\mathrm{c}$ show the DRE of total OA from the Base and Modified_Age simulations. The global mean value of all-sky DRE is -0.290 and $-0.344 \mathrm{Wm}^{-2}$ in Base and Modified_Age, at the top of the atmosphere. This number is $-0.392 \mathrm{Wm}^{-2}$ when assuming OA does not absorb light. Therefore the global mean absorption DRE from OA $(\mathrm{BrC})$ is estimated to be +0.102 and $+0.048 \mathrm{Wm}^{-2}$ in Base and Modified_Age. In the Modified_Age simulation, biofuel and biomass burning sources contribute 60 and $40 \%$ respectively to the global absorption DRE of BrC. The absorption DRE of BrC from our best (Modified_Age) simulation $\left(+0.048 \mathrm{Wm}^{-2}\right)$ is about $30 \%$ of the DRE from BC $\left(+0.17 \mathrm{Wm}^{-2}\right)$. The aging process significantly impacts our estimate of the absorption DRE; the global absorption DRE is $43 \%$ higher when using the same optical assumptions but excluding the aging scheme in Modified_Age. We also find that the global mean absorption DRE is very similar using the Modified_Simple scheme $\left(+0.049 \mathrm{Wm}^{-2}\right)$ or the Modified_Age scheme, both of which are observationally constrained.

The DRE could be underestimated due to two reasons: First, we attribute all the mass bias of OA to biomass burning OA during fire plumes without considering other sources. This may overestimate the contribution of biomass burning in our analysis, thereby underestimating the MAC of biomass burning OA when constrained by absorption observations in fire plumes. Using a potentially underestimated MAC globally could result in an underestimate of the global DRE. Second, we neglect some very high OA absorption at high altitudes $(>10 \mathrm{~km})$. Zhang et al. (2017) suggest that this contributes a local DRE of $0.65 \pm 0.34 \mathrm{Wm}^{2}$. However it is unclear how important this convectively formed $\mathrm{BrC}$ is globally; therefore we neglect it here, implying that our estimate of absorption DRE of $\mathrm{BrC}$ is a lower estimate.

In contrast, the DRE could also be overestimated for two reasons. First, if we assume that biofuel $\mathrm{BrC}$ is subject to the same aging process as biomass burning $\mathrm{BrC}$, the global absorption DRE would be $37 \%$ lower than our estimate. Second, we assume that $\mathrm{BrC}$ is completely externally mixed with other aerosols. This will overestimate the absorption since the $\mathrm{BrC}$ coated on $\mathrm{BC}$ is also counted (via an absorption enhancement factor). Assuming the shell thickness is $\sim 60 \%$ of the core radius (observed in field measurements; Cross et al., 2010; Shiraiwa et al., 2010), and all coated material is $\mathrm{BrC}$ for biofuel/biomass burning related $\mathrm{BC}$, the absorption DRE of $\mathrm{BrC}$ will be $\sim 15 \%$ lower. This effect is likely even smaller given that $\mathrm{BrC}$ may contribute little to the coat- 

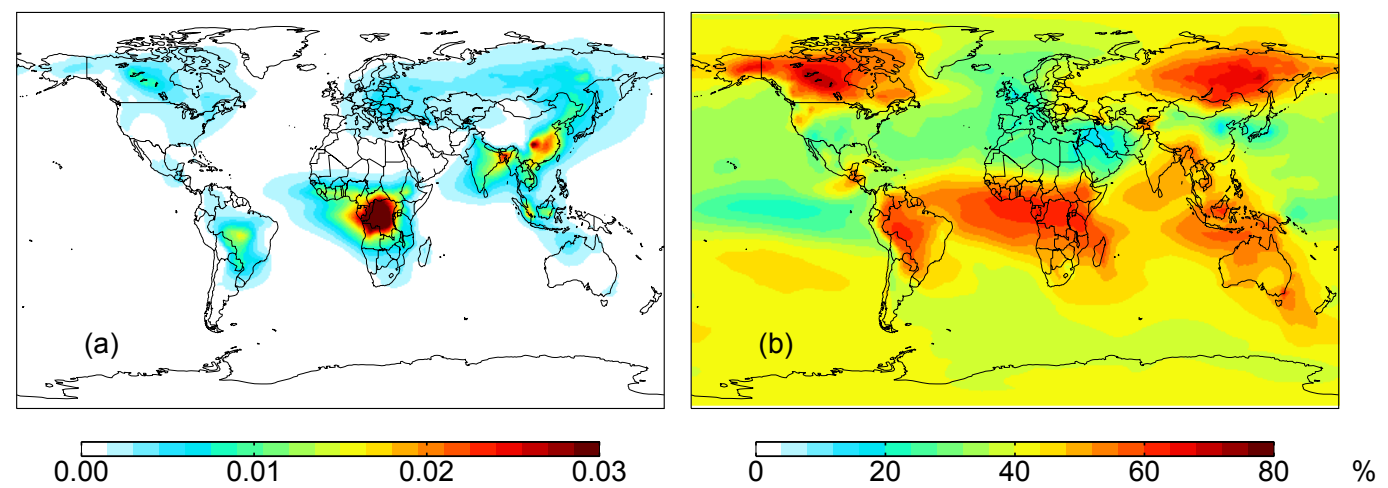

Figure 8. Global distribution of simulated 2014 annual mean (a) BrC AAOD, and (b) contribution of BrC AAOD to total AAOD at $440 \mathrm{~nm}$. Results are from the Modified_Age simulation.
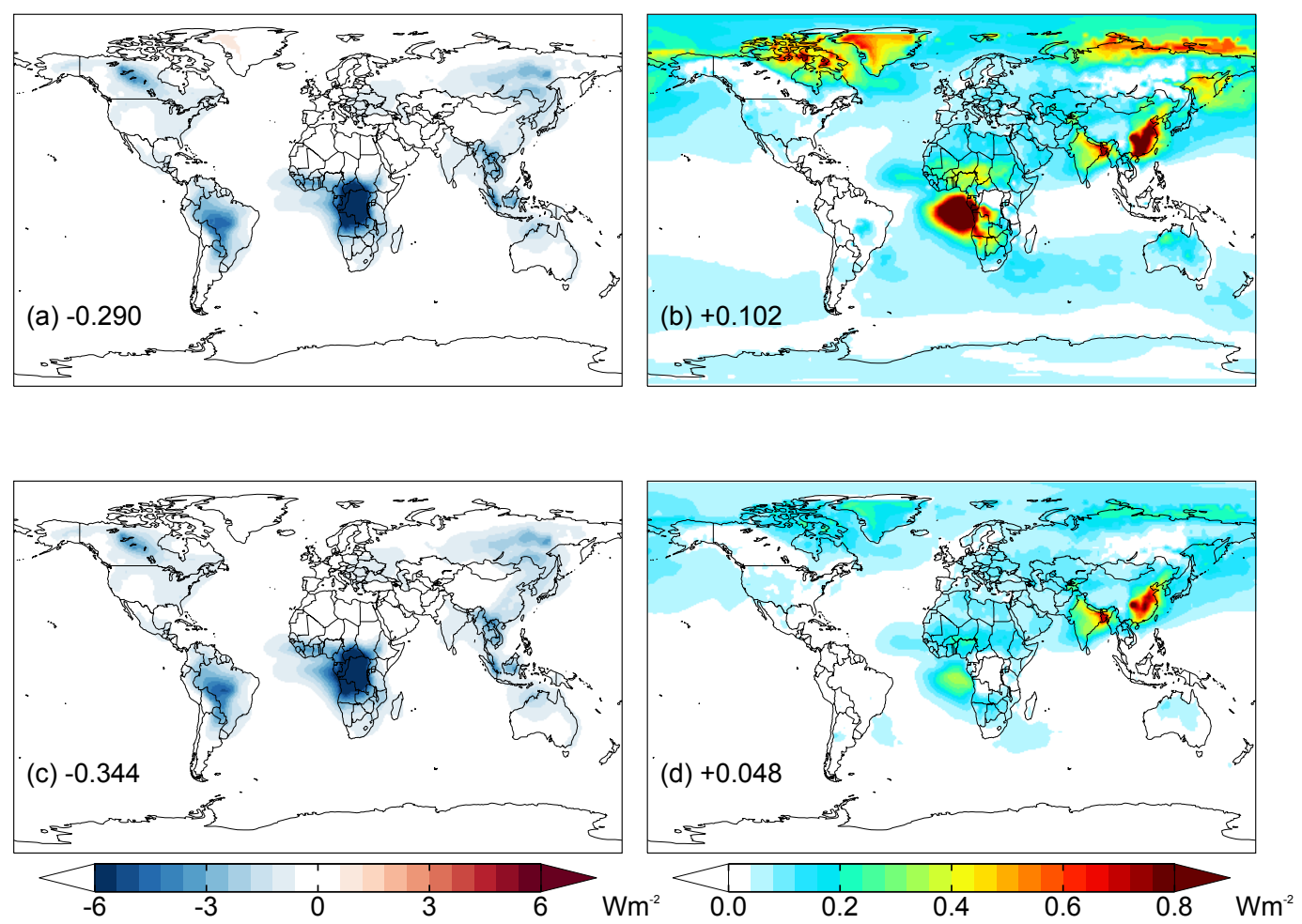

Figure 9. The global annual mean OA DRE (a, c) and BrC absorption DRE (b, d) at the top of the atmosphere (TOA) in 2014 from Base (a, b) and Modified_Age (c, d) simulations. Numbers indicate the global mean value in $\mathrm{Wm}^{-2}$.

ing material compared to non-absorbing $\mathrm{OA}$ and nonorganic aerosols.

Our estimate of BrC DRE is near the lower bound of previous studies, which have not been evaluated against direct measurements of $\mathrm{BrC}$ absorption. Saleh et al. (2015) apply $\mathrm{BrC}$ absorption properties based on the modeled $\mathrm{BC} / \mathrm{OA}$ ratio and estimate the absorption DRE from $\mathrm{BrC}$ to be +0.12 to $+0.22 \mathrm{Wm}^{-2}$. Jo et al. (2016) use the modified combustion efficiency (MCE, a function of $\mathrm{CO} / \mathrm{CO}_{2}$ ) to determine $\mathrm{BrC}$ absorption and estimate the absorption BrC DRE to be $+0.11 \mathrm{Wm}^{-2}$. These values are similar to the absorption DRE of BrC estimated from our Base simulation, prior to optimization against observations. Hammer et al. (2016) estimate an absorption BrC DRE of $+0.03 \mathrm{Wm}^{-2}$, which is the lowest value from previous studies, and lower than our estimate. We note that their model is constrained by satellite observations of the ultraviolet aerosol index (UVAI), which is not specific to BrC; furthermore, uncertainties in the UVAI product are not well understood. More widespread direct 
measurements of $\mathrm{BrC}$ absorption may offer opportunities to evaluate the UVAI product.

In this study, we do not estimate the DRF, which is the difference between pre-industrial and present-day DRE, given the challenges in identifying the anthropogenic fraction of biomass burning emissions. Several previous studies report the absorption DRF for BrC: +0.04 to $+0.11 \mathrm{Wm}^{-2}$ by Feng et al. (2013) and +0.22 to $+0.57 \mathrm{Wm}^{-2}$ by Lin et al. (2014).

\section{Conclusions}

We use the GEOS-Chem model coupled with the RRTMG model to investigate the mass optical properties and direct radiative effect of brown carbon $(\mathrm{BrC})$. Our model assumptions for the optical properties of $\mathrm{BrC}$ are based on the laboratory study of Saleh et al. (2014) and constrained by the aircraft measurements from the DC3 campaign in the United States. These assumptions are further tested against observations made during the $\mathrm{SEAC}^{4} \mathrm{RS}$ campaigns.

Our model captures the magnitude and vertical distribution of sulfate and $\mathrm{BC}$ mass concentrations during both DC3 and SEAC ${ }^{4}$ RS. However, the model underestimates the OA mass concentrations in both campaigns. By analyzing the fire plumes in the observations, we find the biomass burning OA is likely to be underestimated by $80 \%$ due to the bias in OA emission factors and/or missing biomass burning related SOA. After fixing the OA mass from biomass burning, our model is able to represent the variation of OA absorption in fire plumes but substantially overestimates the magnitude. Applying an aging scheme where OA photochemically whitens further increases the correlation between modeled and observed absorption and decreases the model bias. These comparisons suggest fire emissions are characterized by an $\mathrm{MAC}_{\mathrm{OA}}$ of $1.33 \mathrm{~m}^{2} \mathrm{~g}^{-1}$ at $365 \mathrm{~nm}, 0.77 \mathrm{~m}^{2} \mathrm{~g}^{-1}$ at $440 \mathrm{~nm}$, and $0.35 \mathrm{~m}^{2} \mathrm{~g}^{-1}$ at $550 \mathrm{~nm}$, which decreases with aging. The optical properties for biofuel emissions are not well constrained by these datasets, and we retain our original assumptions based on Saleh et al. (2014) with biofuel $\mathrm{MAC}_{\mathrm{OA}}$ of $1.19 \mathrm{~m}^{2} \mathrm{~g}^{-1}$ at $365 \mathrm{~nm}$, $0.76 \mathrm{~m}^{2} \mathrm{~g}^{-1}$ at $440 \mathrm{~nm}$, and $0.39 \mathrm{~m}^{2} \mathrm{~g}^{-1}$ at $550 \mathrm{~nm}$. Using these assumptions, we estimate a global mean top-of-theatmosphere DRE of $-0.344 \mathrm{Wm}^{-2}$ for OA and an absorption DRE of $+0.048 \mathrm{Wm}^{-2}$ for BrC in all-sky conditions. These properties and the resulting estimated DRE are lower than values from most previous modeling studies; however, none of these studies have been constrained by or evaluated against direct $\mathrm{BrC}$ absorption measurements.

Although the model can reproduce the aircraft observations from $\mathrm{DC} 3$ and $\mathrm{SEAC}^{4} \mathrm{RS}$ when using the above model configuration, further studies, especially global, direct measurements, are necessary to build a credible simulation of BrC. First, current emission inventories do not provide enough information to accurately apply combustion condition based $\mathrm{BrC}$ absorption properties. Emission mea- surements representative of varying burning conditions as well as different fuel types are needed. Second, we extend the model assumptions constrained from regional observations (mainland United States) to a global simulation. It is not clear whether $\mathrm{BrC}$ properties are consistent worldwide. Third, more studies are required to investigate the contribution of biomass burning SOA and its absorptivity. Fourth, the whitening scheme needs to be further evaluated by future measurements. Previous near-source direct observations of $\mathrm{BrC}$ absorption have been limited by low temporal resolution and/or the absence of accompanying measurements of other species (Liu et al., 2013; Washenfelder et al., 2015; Zhang et al., 2013) and have therefore not been able to provide the much needed constraints on the photochemical aging state or transport time. Fifth, the absorption assumptions for biofuel OA must be more thoroughly evaluated. It is also not clear whether the whitening process also affects the absorption of biofuel OA. Last, our simulations do not include OA absorption from fossil fuels. Fossil OA has only been identified as light-absorbing in Beijing (Yan et al., 2017). However, applying this assumption for fossil OA worldwide in the model would substantially increase background OA absorption, leading to a considerable model overestimate of OA absorption observed during aircraft campaigns (Sect. 4) and OA absorption contributions from surface sites (Sect. 5.1). Therefore, to further constrain the global impacts of $\mathrm{BrC}$, additional field measurements representative of various source influences (fossil, biofuel OA, SOA) are required.

Data availability. All data of aircraft measurements used in this paper were collected as part of the NASA DC3 and SEAC ${ }^{4} \mathrm{RS}$ missions and are available to the general public through the NASA data archive (https://www-air.larc.nasa.gov/cgi-bin/ArcView/dc3 and https://www-air.larc.nasa.gov/cgi-bin/ArcView/seac4rs). The GEOS-Chem model results are available from the corresponding author upon request.

Competing interests. The authors declare that they have no conflict of interest.

Acknowledgements. This work was supported by EPA (RD83503301-0) and NOAA (NA16OAR4310112). Rodney J. Weber was supported through a NASA Radiation Sciences Program grant NNX14AP74G. Pedro Campuzano-Jost and Jose L. Jimenez were supported by NASA NNX15AT96G. Joshua P. Schwarz and Anne E. Perring were supported by the NOAA Atmospheric Composition and Climate Program, the NASA Radiation Sciences Program, and the NASA Upper Atmosphere Research Program.

Edited by: Qiang Zhang

Reviewed by: two anonymous referees 


\section{References}

Aiken, A. C., Decarlo, P. F., Kroll, J. H., Worsnop, D. R., Huffman, J. A., Docherty, K. S., Ulbrich, I. M., Mohr, C., Kimmel, J. R., Sueper, D., Sun, Y., Zhang, Q., Trimborn, A., Northway, M., Ziemann, P. J., Canagaratna, M. R., Onasch, T. B., Alfarra, M. R., Prevot, A. S. H., Dommen, J., Duplissy, J., Metzger, A., Baltensperger, U., and Jimenez, J. L.: O / C and OM / OC ratios of primary, secondary, and ambient organic aerosols with high-resolution time-of-flight aerosol mass spectrometry, Environ. Sci. Technol., 42, 4478-4485, 2008.

Andrea, M. O. and Merlet P.: Emission of trace gases and aerosols from biomass burning, Global Biogeochem. Cy., 15, 955-966, 2001.

Andreae, M. O. and Gelencsér, A.: Black carbon or brown carbon? The nature of light-absorbing carbonaceous aerosols, Atmos. Chem. Phys., 6, 3131-3148, https://doi.org/10.5194/acp-63131-2006, 2006.

Arola, A., Schuster, G., Myhre, G., Kazadzis, S., Dey, S., and Tripathi, S. N.: Inferring absorbing organic carbon content from AERONET data, Atmos. Chem. Phys., 11, 215-225, https://doi.org/10.5194/acp-11-215-2011, 2011.

Barth, M. C., Cantrell, C. A., Brune, W. H., Rutledge, S. A., Crawford, J. H., Huntrieser, H., Carey, L. D., MacGorman, D., Weisman, M., Pickering, K. E., Bruning, E., Anderson, B., Apel, E., Biggerstaff, M., Campos, T., Campuzano-Jost, P., Cohen, R., Crounse, J., Day, D. A., Diskin, G., Flocke, F., Fried, A., Garland, C., Heikes, B., Honomichl, S., Hornbrook, R., Huey, L. G., Jimenez, J., Lang, T., Lichtenstern, M., Mikoviny, T., Nault, B., O’Sullivan, D., Pan, L., Peischl, J., Pollack, I., Richter, D., Riemer, D., Ryerson, T., Schlager, H., St. Clair, J., Walega, J., Weibring, P., Weinheimer, A., Wennberg, P., Wisthaler, A., Wooldridge, P., and Ziegler, C.: The Deep Convective Clouds and Chemistry (DC3) Field Campaign, B. Am. Meteorol. Soc., 96, 1281-1309, https://doi.org/10.1175/BAMSD-13-00290.1, 2015.

Bey, I., Jacob, D. J., Yantosca, R. M., Logan, J. A., Field, B., Fiore, A. M., Li, Q., Liu, H., Mickley, L. J., and Schultz, M.: Global modeling of tropospheric chemistry with assimilated meteorology: Model description and evaluation, J. Geophys. Res., 106, 23073-23095, 2001.

Bond, T. C. and Bergstrom, R. W.: Light absorption by carbonaceous particles: an investigative review, Aerosol Sci. Tech., 40, 27-67, https://doi.org/10.1080/02786820500421521, 2006.

Bond, T. C., Habib, G., and Bergstrom, R. W.: Limitations in the enhancement of visible light absorption due to mixing state, J. Geophys. Res., 111, D20211, https://doi.org/10.1029/2006JD007315, 2006.

Bond, T. C., Bhardwaj, E., Dong, R., Jogani, R., Jung, S. K., Roden, C., Streets, D. G., and Trautmann, N. M.: Historical emissions of black and organic carbon aerosol from energy-related combustion, 1850-2000, Global Biogeochem. Cy., 21, GB2018, https://doi.org/10.1029/2006GB002840, 2007.

Bond, T. C., Doherty, S., Fahey, D., Forster, P., Berntsen, T., DeAngelo, B., Flanner, M., Ghan, S., Kärcher, B., and Koch, D.: Bounding the role of black carbon in the climate system: A scientific assessment, J. Geophys. Res.-Atmos., 118, 5380-5552, https://doi.org/10.1002/jgrd.50171, 2013.

Canagaratna, M. R., Jimenez, J. L., Kroll, J. H., Chen, Q., Kessler, S. H., Massoli, P., Hildebrandt Ruiz, L., Fortner, E., Williams, L.
R., Wilson, K. R., Surratt, J. D., Donahue, N. M., Jayne, J. T., and Worsnop, D. R.: Elemental ratio measurements of organic compounds using aerosol mass spectrometry: characterization, improved calibration, and implications, Atmos. Chem. Phys., 15, 253-272, https://doi.org/10.5194/acp-15-253-2015, 2015.

Chen, Y. and Bond, T. C.: Light absorption by organic carbon from wood combustion, Atmos. Chem. Phys., 10, 1773-1787, https://doi.org/10.5194/acp-10-1773-2010, 2010.

China, S., Scarnato, B., Owen, R. C., Zhang, B., Ampadu, M. T., Kumar, S., Dzepina, K., Dziobak, M. P., Fialho, P., Perlinger, J. A., Hueber, J., Helmig, D., Mazzoleni, L. R., and Mazzoleni, C.: Morphology and mixing state of aged soot particles at a remote marine free troposphere site: implications for optical properties, Geophys. Res. Lett., 42, 1243-1250, https://doi.org/10.1002/2014GL062404, 2015.

Cross, E. S., Onasch, T. B., Ahern, A., Wrobel, W., Slowik, J. G., Olfert, J., Lack, D. A., Massoli, P., Cappa, C. D., Schwarz, J. P., Spackman, J. R., Fahey, D. W., Sedlacek, A., Trimborn, A., Jayne, J. T., Freedman, A., Williams, L. R., Ng, N. L., Mazzoleni, C., Dubey, M., Brem, B., Kok, G., Subramanian, R., Freitag, S., Clarke, A., Thornhill, D., Marr, L. C., Kolb, C. E., Worsnop, D. R., and Davidovits, P.: Soot Particle Studies - Instrument InterComparison - Project Overview, Aerosol Sci. Tech., 44, 592611, 2010.

Cubison, M. J., Ortega, A. M., Hayes, P. L., Farmer, D. K., Day, D., Lechner, M. J., Brune, W. H., Apel, E., Diskin, G. S., Fisher, J. A., Fuelberg, H. E., Hecobian, A., Knapp, D. J., Mikoviny, T., Riemer, D., Sachse, G. W., Sessions, W., Weber, R. J., Weinheimer, A. J., Wisthaler, A., and Jimenez, J. L.: Effects of aging on organic aerosol from open biomass burning smoke in aircraft and laboratory studies, Atmos. Chem. Phys., 11, 12049-12064, https://doi.org/10.5194/acp-11-12049-2011, 2011.

DeCarlo, P. F., Kimmel, J. R., Trimborn, A., Northway, M. J., Jayne, J. T., Aiken, A. C., Gonin, M., Fuhrer, K., Horvath, T., Docherty, K. S., Worsnop, D. R., and Jimenez, J. L.: Field-deployable, high-resolution, time-of-flight aerosol mass spectrometer, Anal. Chem., 78, 8281-8289, https://doi.org/10.1021/ac061249n, 2006.

Desyaterik, Y., Sun, Y., Shen, X., Lee, T., Wang, X., Wang, T., and Collett Jr., J. L.: Speciation of "brown" carbon in cloud water impacted by agricultural biomass burning in eastern China, J. Geophys. Res.-Atmos., 118, 7389-7399, https://doi.org/10.1002/jgrd.50561, 2013.

Drury, E. E., Jacob, D. J., Spurr, R. J. D.,Wang, J., Shinozuka, Y., Anderson, B. E., Clarke, A. D., Dibb, J., McNaughton, C., and Weber, R. J.: Synthesis of satellite (MODIS), aircraft (ICARTT), and surface (IMPROVE, EPA-AQS, AERONET) aerosol observations over eastern North America to improve MODIS aerosol retrievals and constrain aerosol concentrations and sources, J. Geophys. Res.-Atmos., 115, D14204, https://doi.org/10.1029/2009JD012629, 2010.

Dunlea, E. J., DeCarlo, P. F., Aiken, A. C., Kimmel, J. R., Peltier, R. E., Weber, R. J., Tomlinson, J., Collins, D. R., Shinozuka, Y., McNaughton, C. S., Howell, S. G., Clarke, A. D., Emmons, L. K., Apel, E. C., Pfister, G. G., van Donkelaar, A., Martin, R. V., Millet, D. B., Heald, C. L., and Jimenez, J. L.: Evolution of Asian aerosols during transpacific transport in INTEX-B, Atmos. Chem. Phys., 9, 7257-7287, https://doi.org/10.5194/acp-9-72572009, 2009. 
Ervens, B., Turpin, B. J., and Weber, R. J.: Secondary organic aerosol formation in cloud droplets and aqueous particles (aqSOA): a review of laboratory, field and model studies, Atmos. Chem. Phys., 11, 11069-11102, https://doi.org/10.5194/acp-1111069-2011, 2011.

Feng, Y., Ramanathan, V., and Kotamarthi, V. R.: Brown carbon: a significant atmospheric absorber of solar radiation?, Atmos. Chem. Phys., 13, 8607-8621, https://doi.org/10.5194/acp13-8607-2013, 2013.

Flores, J. M., Washenfelder, R. A., Adler, G., Lee, H. J., Segev, L., Laskin, J., Laskin, A., Nizkorodov, S. A., Brown, S. S., and Rudich, Y.: Complex refractive indices in the near-ultraviolet spectral region of biogenic secondary organic aerosol aged with ammonia, Phys. Chem. Chem. Phys., 16, 10629-10642, 2014.

Forrister, H., Liu, J., Scheuer, E., Dibb, J., Ziemba, L., Thornhill, K. L., Anderson, B., Diskin, G., Perring, A. E., Schwarz, J. P., Campuzano-Jost, P., Day, D. A., Palm, B. B., Jimenez, J. L., Nenes, A., and Weber, R. J.: Evolution of brown carbon in wildfire plumes, Geophys. Res. Lett., 42, 4623-4630, 2015.

Giglio, L., Randerson, J. T., and van der Werf, G. R.: Analysis of daily, monthly, and annual burned area using the fourth generation global fire emissions database (GFED4) J. Geophys. Res.Biogeo., 118, 317-328, 2013.

Gilardoni, S., Massoli, P., Paglione, M., Giulianelli, L., Carbone, C., Rinaldi, M., Decesari, S., Sandrini, S., Costabile, F., Gobbi, G. P., Pietrogrande, M. C., Visentin, M., Scotto, F., Fuzzi, S., and Facchini, M. C.: Direct observation of aqueous secondary organic aerosol from biomassburning emissions, P. Natl. Acad. Sci. USA, 113, 10013-10018, https://doi.org/10.1073/pnas.1602212113, 2016.

Graber, E. R. and Rudich, Y.: Atmospheric HULIS: How humiclike are they? A comprehensive and critical review, Atmos. Chem. Phys., 6, 729-753, https://doi.org/10.5194/acp-6-7292006, 2006.

Guenther, A. B., Jiang, X., Heald, C. L., Sakulyanontvittaya, T., Duhl, T., Emmons, L. K., and Wang, X.: The Model of Emissions of Gases and Aerosols from Nature version 2.1 (MEGAN2.1): an extended and updated framework for modeling biogenic emissions, Geosci. Model Dev., 5, 1471-1492, https://doi.org/10.5194/gmd-5-1471-2012, 2012.

Hammer, M. S., Martin, R. V., van Donkelaar, A., Buchard, V., Torres, O., Ridley, D. A., and Spurr, R. J. D.: Interpreting the ultraviolet aerosol index observed with the OMI satellite instrument to understand absorption by organic aerosols: implications for atmospheric oxidation and direct radiative effects, Atmos. Chem. Phys., 16, 2507-2523, https://doi.org/10.5194/acp16-2507-2016, 2016.

Heald, C. L., Coe, H., Jimenez, J. L., Weber, R. J., Bahreini, R., Middlebrook, A. M., Russell, L. M., Jolleys, M., Fu, T.-M., Allan, J. D., Bower, K. N., Capes, G., Crosier, J., Morgan, W. T., Robinson, N. H., Williams, P. I., Cubison, M. J., DeCarlo, P. F., and Dunlea, E. J.: Exploring the vertical profile of atmospheric organic aerosol: comparing 17 aircraft field campaigns with a global model, Atmos. Chem. Phys., 11, 12673-12696, https://doi.org/10.5194/acp-11-12673-2011, 2011.

Heald, C. L., Ridley, D. A., Kroll, J. H., Barrett, S. R. H., Cady-Pereira, K. E., Alvarado, M. J., and Holmes, C. D.: Contrasting the direct radiative effect and direct radiative forcing of aerosols, Atmos. Chem. Phys., 14, 5513-5527, https://doi.org/10.5194/acp-14-5513-2014, 2014.

Hecobian, A., Zhang, X., Zheng, M., Frank, N., Edgerton, E. S., and Weber, R. J.: Water-Soluble Organic Aerosol material and the light-absorption characteristics of aqueous extracts measured over the Southeastern United States, Atmos. Chem. Phys., 10, 5965-5977, https://doi.org/10.5194/acp-10-5965-2010, 2010.

Hodzic, A. and Jimenez, J. L.: Modeling anthropogenically controlled secondary organic aerosols in a megacity: a simplified framework for global and climate models, Geosci. Model Dev., 4, 901-917, https://doi.org/10.5194/gmd-4-901-2011, 2011.

Iacono, M. J., Delamere, J. S., Mlawer, E. J., Shephard, M. W., Clough, S. A., and Collins, W. D.: Radiative forcing by long-lived greenhouse gases: calculations with the AER radiative transfer models, J. Geophys. Res.-Atmos., 113, D13103, https://doi.org/10.1029/2008jd009944, 2008.

Jacobson, M. Z.: Strong radiative heating due to the mixing state of black carbon in atmospheric aerosols, Nature, 409, 695-697, 2001.

Jaoui, M., Edney, E. O., Kleindienst, T. E., Lewandowski, M., Offenberg, J. H., Surratt, J. D., and Seinfeld, J. H.: Formation of secondary organic aerosol from irradiated $\alpha$-pinene/toluene/ $\mathrm{NO}_{x}$ mixtures and the effect of isoprene and sulfur dioxide, J. Geophys. Res., 113, D09303, https://doi.org/10.1029/2007JD009426, 2008.

Jo, D. S., Park, R. J., Lee, S., Kim, S.-W., and Zhang, X.: A global simulation of brown carbon: implications for photochemistry and direct radiative effect, Atmos. Chem. Phys., 16, 3413-3432, https://doi.org/10.5194/acp-16-3413-2016, 2016.

Jolleys, M. D., Coe, H., McFiggans, G., Capes, G., Allan, J. D., Crosier, J., Williams, P. I., Allen, G., Bower, K. N., Jimenez, J. J., Russell, L. M., Grutter, M., and Baumgardner D.: Characterizing the Aging of Biomass Burning Organic Aerosol by Use of Mixing Ratios: A Meta-analysis of Four Regions, Environ. Sci Technol., 46, 13093-13102, https://doi.org/10.1021/es302386v, 2012.

Kim, P. S., Jacob, D. J., Fisher, J. A., Travis, K., Yu, K., Zhu, L., Yantosca, R. M., Sulprizio, M. P., Jimenez, J. L., CampuzanoJost, P., Froyd, K. D., Liao, J., Hair, J. W., Fenn, M. A., Butler, C. F., Wagner, N. L., Gordon, T. D., Welti, A., Wennberg, P. O., Crounse, J. D., St. Clair, J. M., Teng, A. P., Millet, D. B., Schwarz, J. P., Markovic, M. Z., and Perring, A. E.: Sources, seasonality, and trends of southeast US aerosol: an integrated analysis of surface, aircraft, and satellite observations with the GEOS-Chem chemical transport model, Atmos. Chem. Phys., 15, 10411-10433, https://doi.org/10.5194/acp-15-104112015, 2015.

Kirchstetter, T. W., T. Novakov, and P. V. Hobbs: Evidence that the spectral dependence of light absorption by aerosols is affected by organic carbon, J. Geophys. Res., 109, D21208, https://doi.org/10.1029/2004JD004999, 2004.

Koch, D., Schulz, M., Kinne, S., McNaughton, C., Spackman, J. R., Balkanski, Y., Bauer, S., Berntsen, T., Bond, T. C., Boucher, O., Chin, M., Clarke, A., De Luca, N., Dentener, F., Diehl, T., Dubovik, O., Easter, R., Fahey, D. W., Feichter, J., Fillmore, D., Freitag, S., Ghan, S., Ginoux, P., Gong, S., Horowitz, L., Iversen, T., Kirkevåg, A., Klimont, Z., Kondo, Y., Krol, M., Liu, X., Miller, R., Montanaro, V., Moteki, N., Myhre, G., Penner, J. E., Perlwitz, J., Pitari, G., Reddy, S., Sahu, L., Sakamoto, H., 
Schuster, G., Schwarz, J. P., Seland, Ø., Stier, P., Takegawa, N., Takemura, T., Textor, C., van Aardenne, J. A., and Zhao, Y.: Evaluation of black carbon estimations in global aerosol models, Atmos. Chem. Phys., 9, 9001-9026, https://doi.org/10.5194/acp-99001-2009, 2009.

Kondo, Y., Matsui, H., Moteki, N., Sahu, L., Takegawa, N., Kajino, M., Zhao, Y., Cubison, M. J., Jimenez, J. L., Vay, S., Diskin, G. S., Anderson, B., Wisthaler, A., Mikoviny, T., Fuelberg, H. E., Blake, D. R., Huey, G., Weinheimer, A. J., Knapp, D. J., and Brune, W. H.: Emissions of black carbon, organic, and inorganic aerosols from biomass burning in North America and Asia in 2008, J. Geophys. Res., 116, D08204, https://doi.org/10.1029/2010JD015152, 2011.

Kopke, P., Hess, M., Schult, I., and Shettle, E. P.: Global Aerosol Data Set, Max Planck Inst. für Meteorol, Hamburg, Germany, 1997.

Laskin, A., Laskin, J., and Nizkorodov, S. A.: Chemistry of atmospheric brown carbon, Chem. Rev., 115, 4335-4382, 2015.

Lee, H. J., Aiona, P. K., Laskin, A., Laskin, J., and Nizkorodov, S. A.: Effect of Solar Radiation on the Optical Properties and Molecular Composition of Laboratory Proxies of Atmospheric Brown Carbon, Environ. Sci. Technol., 48, 10217-10226, 2014.

Lin, G., Penner, J. E., Flanner, M. G., Sillman, S., Xu, L., and Zhou, C.: Radiative forcing of organic aerosol in the atmosphere and on snow: effects of SOA and brown carbon, J. Geophys. Res.Atmos., 119, 7453-7476, 2014.

Liu, J., Fan, S., Horowitz, L. W., and Levy II, H.: Evaluation of factors controlling long-range transport of black carbon to the Arctic, J. Geophys. Res., 116, D04307, https://doi.org/10.1029/2010JD015145, 2011.

Liu, J., Bergin, M., Guo, H., King, L., Kotra, N., Edgerton, E., and Weber, R. J.: Size-resolved measurements of brown carbon in water and methanol extracts and estimates of their contribution to ambient fine-particle light absorption, Atmos. Chem. Phys., 13, 12389-12404, https://doi.org/10.5194/acp-13-123892013, 2013.

Liu, J., Scheuer, E., Dibb, J., Diskin, G. S., Ziemba, L. D., Thornhill, K. L., Anderson, B. E., Wisthaler, A., Mikoviny, T., Devi, J. J., Bergin, M., Perring, A. E., Markovic, M. Z., Schwarz, J. P., Campuzano-Jost, P., Day, D. A., Jimenez, J. L., and Weber, R. J.: Brown carbon aerosol in the North American continental troposphere: sources, abundance, and radiative forcing, Atmos. Chem. Phys., 15, 7841-7858, https://doi.org/10.5194/acp15-7841-2015, 2015.

Liu, J., Lin, P., Laskin, A., Laskin, J., Kathmann, S. M., Wise, M., Caylor, R., Imholt, F., Selimovic, V., and Shilling, J. E.: Optical properties and aging of light-absorbing secondary organic aerosol, Atmos. Chem. Phys., 16, 12815-12827, https://doi.org/10.5194/acp-16-12815-2016, 2016.

Moffet, R. C. and Prather, K. A.: In-situ measurements of the mixing state and optical properties of soot with implications for radiative forcing estimates, P. Natl. Acad. Sci. USA, 106, 1187211877, https://doi.org/10.1073/pnas.0900040106, 2009.

Ortega, A. M., Day, D. A., Cubison, M. J., Brune, W. H., Bon, D., de Gouw, J. A., and Jimenez, J. L.: Secondary organic aerosol formation and primary organic aerosol oxidation from biomassburning smoke in a flow reactor during FLAME-3, Atmos. Chem. Phys., 13, 11551-11571, https://doi.org/10.5194/acp-1311551-2013, 2013.
Park, R. J., Jacob, D. J., Chin, M., and Martin, R. V.: Sources of carbonaceous aerosols over the United States and implications for natural visibility, J. Geophys. Res., 108, 4355, https://doi.org/10.1029/2002JD003190, 2003.

Park, R. J., Kim, M. J., Jeong, J. I., Youn, D., and Kim, S.: A contribution of brown carbon aerosol to the aerosol light absorption and its radiative forcing in East Asia, Atmos. Environ., 44, 14141421, 2010.

Perring, A. E., Schwarz, J. P., Markovic, M. Z., Fahey, D. W., Jimenez, J. L., Campuzano-Jost, P., Palm, B. D., Wisthaler, A., Mikoviny, T., Diskin, G., Sachse, G., Ziemba, L., Anderson, B., Shingler, T., Crosbie, E., Sorooshian A., Tokelson, R., and Gao, R.: In situ measurements of water uptake by black carboncontaining aerosol in wildfire plumes, J. Geophys. Res.-Atmos., 122, 1086-1097, https://doi.org/10.1002/2016JD025688, 2017.

Pokhrel, R. P., Wagner, N. L., Langridge, J. M., Lack, D. A., Jayarathne, T., Stone, E. A., Stockwell, C. E., Yokelson, R. J., and Murphy, S. M.: Parameterization of single-scattering albedo (SSA) and absorption Ångström exponent (AAE) with EC / OC for aerosol emissions from biomass burning, Atmos. Chem. Phys., 16, 9549-9561, https://doi.org/10.5194/acp-169549-2016, 2016.

Pokhrel, R. P., Beamesderfer, E. R., Wagner, N. L., Langridge, J. M., Lack, D. A., Jayarathne, T., Stone, E. A., Stockwell, C. E., Yokelson, R. J., and Murphy, S. M.: Relative importance of black carbon, brown carbon, and absorption enhancement from clear coatings in biomass burning emissions, Atmos. Chem. Phys., 17, 5063-5078, https://doi.org/10.5194/acp-17-5063-2017, 2017.

Pulles, T., van het Bolscher, M., Brand, R., and Visschedijk, A.: Assessment of Global Emissions from Fuel Combustion in the Final Decades of the 20th Century, TNO report A-R0132/B, 2007.

Pye, H. O. T. and Seinfeld, J. H.: A global perspective on aerosol from low-volatility organic compounds, Atmos. Chem. Phys., 10, 4377-4401, https://doi.org/10.5194/acp-10-4377-2010, 2010.

Pye, H. O. T., Chan, A. W. H., Barkley, M. P., and Seinfeld, J. H.: Global modeling of organic aerosol: the importance of reactive nitrogen $\left(\mathrm{NO}_{\mathrm{x}}\right.$ and $\left.\mathrm{NO}_{3}\right)$, Atmos. Chem. Phys., 10, 1126111276, https://doi.org/10.5194/acp-10-11261-2010, 2010.

Ramanathan, V., Li, F., Ramana, M. V., Praveen, P. S., Kim, D., Corrigan, C. E., Nguyen, H., Stone, E. A., Schauer, J. J., Carmichael, G. R., Adhikary, B., and Yoon, S. C.: Atmospheric brown clouds: Hemspherical and regional variations in long-range transport, absorption, and radiative forcing, J. Geophys. Res., 112, D22S21, https://doi.org/10.1029/2006JD008124, 2007.

Saleh, R., Robinson, E. S., Tkacik, D. S., Ahern, A. T., Liu, S., Aiken, A. C., Sullivan, R., C., Presto, A. A., Dubey, M. K., Yokelson, R. J., Donahue, N. M., and Robinson, A. L.: Brownness of organics in aerosols from biomass burning linked to their black carbon content, Nat. Geosci., 7, 647-650, 2014.

Saleh, R., Marks, M., Heo, J., Adams, P. J., Donahue, N. M., and Robinson, A. L.: Contribution of brown carbon and lensing to the direct radiative effect of carbonaceous aerosols from biomass and biofuel burning emissions, J. Geophys. Res.-Atmos., 120, 10285-10296, 2015.

Schwarz, J. P., Gao, R. S., Spackman, J. R., Watts, L. A., Thomson, D. S., Fahey, D. W., Ryerson, T. B., Peischl, J., Holloway, J. S., Trainer, M., Frost, G. J., Baynard, T., Lack, D. A., de Gouw, J. A., Warneke, C., and Del Negro, L. A.: Measurement of the mixing state, mass, and optical size of individual black carbon particles 
in urban and biomass burning emissions, Geophys. Res. Lett., 35, L13810, https://doi.org/10.1029/2008GL033968, 2008.

Shiraiwa, M., Kondo, Y., Iwamoto, T., and Kita, K.: Amplification of Light Absorption of Black Carbon by Organic Coating, Aerosol Sci. Tech., 44, 46-54, 2010.

Shrivastava, M., Cappa, C. D., Fan, J., Goldstein, A. H., Guenther, A. B., Jimenez, J. L., Kuang, C., Laskin, A., Martin, S. T., Ng, N. L., Petaja, T., Pierce, J. R., Rasch, P. J., Roldin, P., Seinfeld, J. H., Shilling, J., Smith, J. N., Thornton, J. A., Volkamer, R., Wang, J., Worsnop, D. R., Zaveri, R. A., Zelenyuk, A., and Zhang, Q.: Recent advances in understanding secondary organic aerosol: Implications for global climate forcing, Rev. Geophys., 55, 509559, https://doi.org/10.1002/2016RG000540, 2017.

Spracklen, D. V., Jimenez, J. L., Carslaw, K. S., Worsnop, D. R., Evans, M. J., Mann, G. W., Zhang, Q., Canagaratna, M. R., Allan, J., Coe, H., McFiggans, G., Rap, A., and Forster, P.: Aerosol mass spectrometer constraint on the global secondary organic aerosol budget, Atmos. Chem. Phys., 11, 12109-12136, https://doi.org/10.5194/acp-11-12109-2011, 2011.

Toon, O. B., Maring, H., Dibb, J., Ferrare, R., Jacob, D. J., Jensen, E. J., Luo, Z. J., Mace, G. G., Pan, L. L., Pfister, L., Rosenlof, K. H., Redemann, J., Reid, J. S., Singh, H. B., Yokelson, R., Chen, G., Jucks, K. W., and Pszenny, A.: Planning, implementation, and scientific goals of the Studies of Em issions and Atmospheric Composition, Clouds and Climate Coupling by Regional Surveys (SEAC ${ }^{4} \mathrm{RS}$ ) field mission, J. Geophys. Res.-Atmos., 121, 49675009, https://doi.org/10.1002/2015JD024297, 2016.

Tsigaridis, K., Daskalakis, N., Kanakidou, M., Adams, P. J., Artaxo, P., Bahadur, R., Balkanski, Y., Bauer, S. E., Bellouin, N., Benedetti, A., Bergman, T., Berntsen, T. K., Beukes, J. P., Bian, H., Carslaw, K. S., Chin, M., Curci, G., Diehl, T., Easter, R. C., Ghan, S. J., Gong, S. L., Hodzic, A., Hoyle, C. R., Iversen, T., Jathar, S., Jimenez, J. L., Kaiser, J. W., Kirkevåg, A., Koch, D., Kokkola, H., Lee, Y. H., Lin, G., Liu, X., Luo, G., Ma, X., Mann, G. W., Mihalopoulos, N., Morcrette, J.-J., Müller, J.-F., Myhre, G., Myriokefalitakis, S., Ng, N. L., O’Donnell, D., Penner, J. E., Pozzoli, L., Pringle, K. J., Russell, L. M., Schulz, M., Sciare, J., Seland, Ø., Shindell, D. T., Sillman, S., Skeie, R. B., Spracklen, D., Stavrakou, T., Steenrod, S. D., Takemura, T., Tiitta, P., Tilmes, S., Tost, H., van Noije, T., van Zyl, P. G., von Salzen, K., Yu, F., Wang, Z., Wang, Z., Zaveri, R. A., Zhang, H., Zhang, K., Zhang, Q., and Zhang, X.: The AeroCom evaluation and intercomparison of organic aerosol in global models, Atmos. Chem. Phys., 14, 10845-10895, https://doi.org/10.5194/acp-1410845-2014, 2014.

Turpin, B. J. and Lim, H. J.: Species contributions to PM2.5 mass concentrations: revisiting common assumptions for estimating organic mass, Aerosol Sci. Tech., 35, 602-610, 2001.

van der Werf, G. R., Randerson, J. T., Giglio, L., Collatz, G. J., Mu, M., Kasibhatla, P. S., Morton, D. C., DeFries, R. S., Jin, Y., and van Leeuwen, T. T.: Global fire emissions and the contribution of deforestation, savanna, forest, agricultural, and peat fires (1997-2009), Atmos. Chem. Phys., 10, 11707-11735, https://doi.org/10.5194/acp-10-11707-2010, 2010.
Wang, Q., Saturno, J., Chi, X., Walter, D., Lavric, J. V., Moran-Zuloaga, D., Ditas, F., Pöhlker, C., Brito, J., Carbone, S., Artaxo, P., and Andreae, M. O.: Modeling investigation of light-absorbing aerosols in the Amazon Basin during the wet season, Atmos. Chem. Phys., 16, 14775-14794, https://doi.org/10.5194/acp-16-14775-2016, 2016.

Wang, X., Heald, C. L., Ridley, D. A., Schwarz, J. P., Spackman, J. R., Perring, A. E., Coe, H., Liu, D., and Clarke, A. D.: Exploiting simultaneous observational constraints on mass and absorption to estimate the global direct radiative forcing of black carbon and brown carbon, Atmos. Chem. Phys., 14, 10989-11010, https://doi.org/10.5194/acp-14-10989-2014, 2014.

Wang, X., Heald, C. L., Sedlacek, A. J., de Sá, S. S., Martin, S. T., Alexander, M. L., Watson, T. B., Aiken, A. C., Springston, S. R., and Artaxo, P.: Deriving brown carbon from multiwavelength absorption measurements: method and application to AERONET and Aethalometer observations, Atmos. Chem. Phys., 16, 1273312752, https://doi.org/10.5194/acp-16-12733-2016, 2016.

Washenfelder, R. A., Attwood, A. R., Brock, C. A., Guo, H., Xu, L., Weber, R. J., Ng, N. L., Allen, H. M., Ayres, B. R., Baumann, K., Cohen, R. C., Draper, D. C., Duffey, K. C., Edgerton, E., Fry, J. L., Hu, W. W., Jimenez, J. L., Palm, B. B., Romer, P., Stone, E. A., Wooldridge, P. J., and Brown, S. S.: Biomass burning dominates brown carbon absorption in the rural southeastern United States, Geophys. Res. Lett., 42, 653-664, https://doi.org/10.1002/2014GL062444, 2015.

Yan, C., Zheng, M., Bosch, C., Andersson, A., Desyaterik, Y., Sullivan, A. P., Collett, J. L., Zhao, B., Wang, S., He, K., and Gustafsson, O.: Important fossil source contribution to brown carbon in Beijing during winter, Sci. Rep., 7, 43182, https://doi.org/10.1038/srep43182, 2017.

Yee, L. D., Kautzman, K. E., Loza, C. L., Schilling, K. A., Coggon, M. M., Chhabra, P. S., Chan, M. N., Chan, A. W. H., Hersey, S. P., Crounse, J. D., Wennberg, P. O., Flagan, R. C., and Seinfeld, J. H.: Secondary organic aerosol formation from biomass burning intermediates: phenol and methoxyphenols, Atmos. Chem. Phys., 13, 8019-8043, https://doi.org/10.5194/acp13-8019-2013, 2013.

Zhang, X. L., Lin, Y. H., Surratt, J. D., and Weber, R. J.: Sources, Composition and Absorption Ångström Exponent of Light absorbing Organic Components in Aerosol Extracts from the Los Angeles Basin, Environ. Sci. Technol., 47, 3685-3693, 2013.

Zhang, Y., Forrister, H., Liu, J., Dibb, J., Anderson, B., Schwarz, J. P., Perring, A. E., Jimenez, J. L., Campuzano-Jost, P., Wang, Y., Nenes, A., and Webber R. J.: Top-of-atmosphere radiative forcing affected by brown carbon in the upper troposphere, Nat. Geosci., 10, 486-489, https://doi.org/10.1038/ngeo2960, 2017.

Zhong, M. and Jang, M.: Light absorption coefficient measurement of SOA using a UV - Visible spectrometer connected with an integrating sphere, Atmos. Environ., 45, 4263-4271, 2011. 